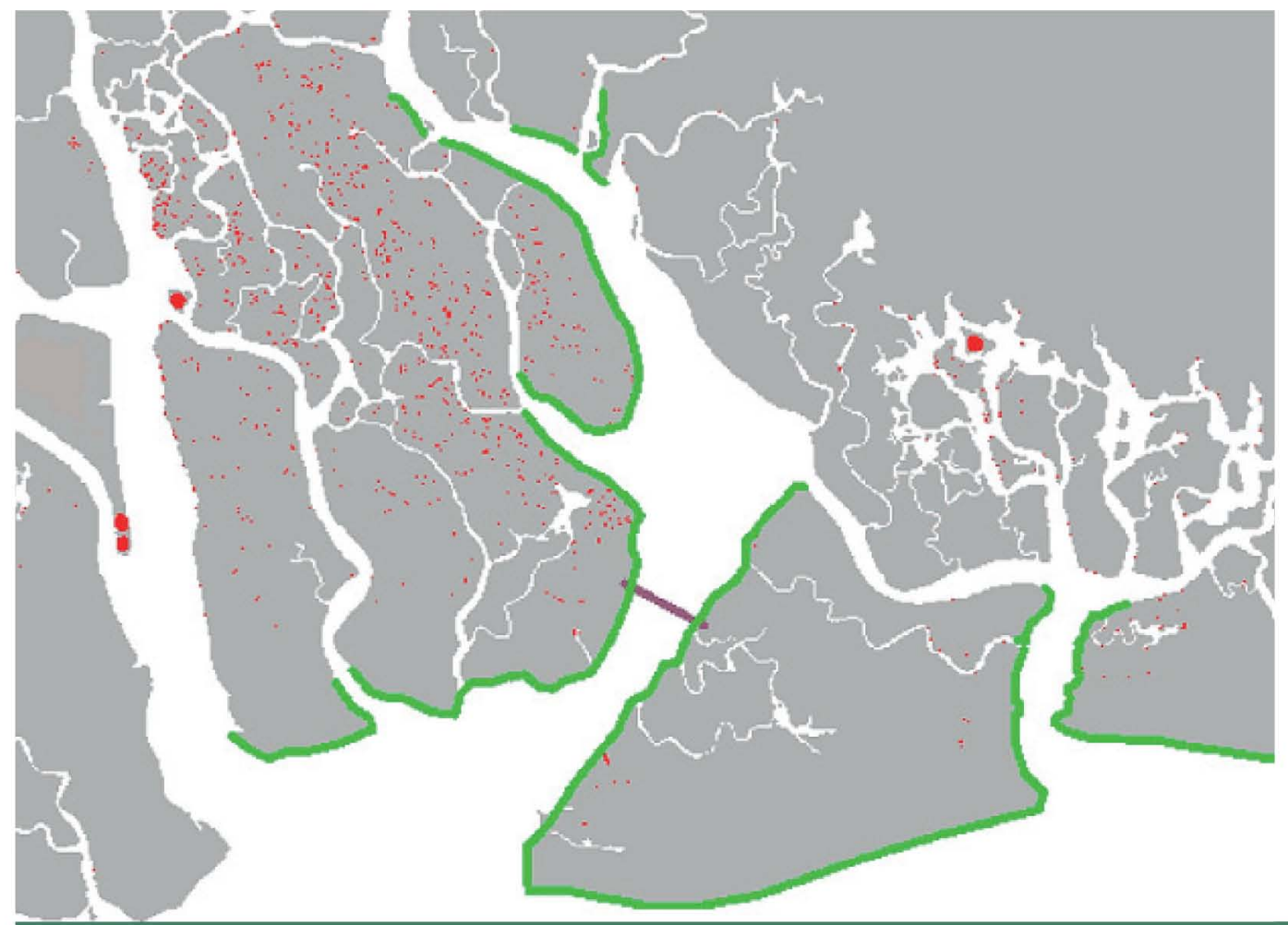

Satellite-Based Mitigation and Adaptation Scenarios for Sea Level Rise in the Lower Niger Delta

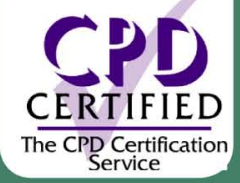

Zahrah Naankwat Musa 


\section{SATELLITE-BASED MITIGATION AND \\ ADAPTATION SCENARIOS FOR SEA LEVEL RISE IN THE LOWER NIGER DELTA}

Zahrah Naankwat Musa 


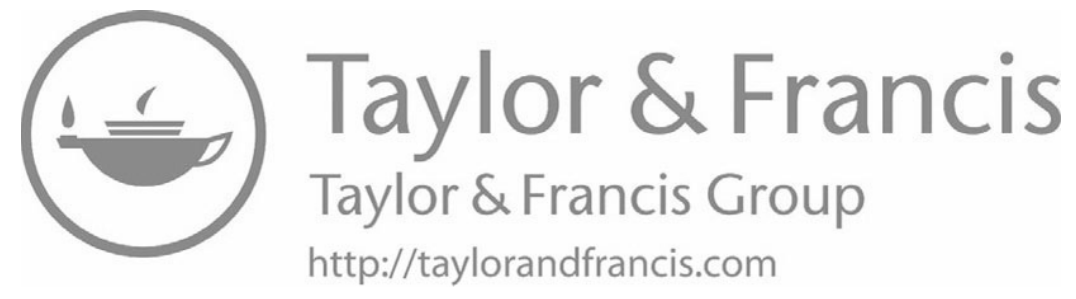




\title{
SATELLITE-BASED MITIGATION AND ADAPTATION SCENARIOS FOR SEA LEVEL RISE IN THE LOWER NIGER DELTA
}

\author{
DISSERTATION
}

Submitted in fulfilment of the requirements of the Board for Doctorates of Delft University of Technology and

of the Academic Board of the IHE Delft Institute for Water Education for the Degree of DOCTOR to be defended in public on Friday, $6^{\text {th }}$ April 2018, at 12:30 hours in Delft, the Netherlands

by

Zahrah Naankwat MUSA

Master of Science in Hydroinformatics

UNESCO-IHE Institute for Water Education

Delft, the Netherlands 
This dissertation has been approved by the supervisors

Prof.dr.ir. A.E. Mynett

Dr. I. Popescu

Composition of the doctoral committee

Chairman

Vice-Chairman

Prof.dr.ir. A.E. Mynett

Dr. I. Popescu

Independent members:

Prof.dr.ir. S.G.J. Aarninkhof

Prof.dr.ir. W.G.M. Bastiaanssen

Prof.dr. F. Martins

Dr.ir. M. van Ledden

Prof.dr.ir. J.A. Roelvink
IHE Delft / Delft University of Technology

IHE Delft / Politehnica University of Timisoara, Romania

Rector Magnificus, Delft University of Technology

Rector IHE Delft

IHE Delft / Delft University of Technology, promotor

IHE Delft / Politehnica University of Timisoara, Romania, copromotor

Delft University of Technology

IHE Delft / Delft University of Technology

Universidade do Algarve Faro, Portugal

World Bank

IHE Delft / Delft University of Technology (reserve member)

This research was conducted under the auspices of the Graduate School for Socio-Economic and Natural Sciences of the Environment (SENSE)

CRC Press/Balkema is an imprint of the Taylor \& Francis Group, an informal business.

\section{(C) 2018, Zahrah N. Musa}

Although all care is taken to ensure integrity and the quality of this publication and the information herein, no responsibility is assumed by the publishers, the author nor IHE Delft for any damage to the property or persons as a result of operation or use of this publication and/or the information contained herein.

A pdf version of this work will be made available as Open Access via http://repository.tuDelft.nl/ihe .This version is licensed under the Creative Commons Attribution-Non Commercial 4.0 International License, http://creativecommons.org/licenses/by-nc/4.0/

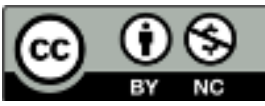

CRC Press/Balkema

PO Box 11320, 2301 EH Leiden, the Netherlands

Pub.NL@taylorandfrancis.com

www.crcpress.com - www.taylorandfrancis.com

ISBN: 978-1-138-60723-1 


\section{Dedication}

Dedicated to the loving memory of my elder brother and greatest cheerleader, Kwapbial Karel

Sallah. You are not here to cheer me bro, but I made it - just like you said I would. 


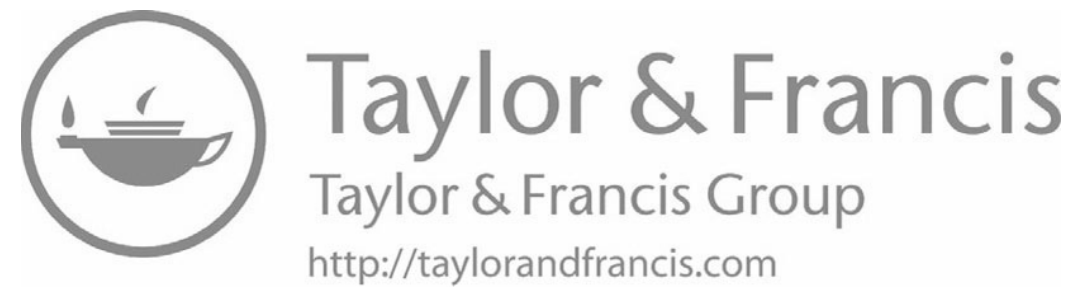




\section{Summary}

Accelerated sea level rise (SLR) is the most important climate change impact for coastal areas. The physical properties of deltas and anthropogenic activities make them vulnerable to the effects of the changing climate; however when evaluation of vulnerabilities is needed many coastal deltas lack necessary data for performing such a task. Leaving these coastal areas without adequate plans to combat sea level rise will cost vulnerable areas huge amounts of losses in lives and properties; e.g. as at 1995, it was estimated that in Nigeria alone, a no-response scenario will cost over $\$ 18$ billion in losses including an estimated 17,000 $\mathrm{km}^{2}$ of wetland (Brown, Kebede, \& Nicolls, 2011).

Data availability is one of the most important factors for analysis, assessment and modelling of physical and other phenomena related to river and coastal systems. Consequently, to reduce the effects of SLR through adaptation and mitigation, the IPCC recommended that coastal areas collect data on physical, social and economic parameters e.g. topographical, land-use, population, tidal wave and range (Dronkers, et al., 1990). Many developing countries however lack measuring equipment and long-term records; Africa generally lacks long-term observational data to aid hydrological research (Niang, et al., 2014). Long-term shoreline dynamics of the Nigerian coastline for instance cannot be predicted since the available data is insufficient to even explain fluctuations during the last hundred years (Orupabo, 2008).

The Niger delta has the highest sensitivity to climate change in Nigeria (it has a very gentle slope and low elevation) and its adaptive capacity is the second lowest in terms of socio- economic development of the country (FME, 2010). The Niger delta is also one of the coastal areas with little data for coastal planning and management, and consequently has poor availability of data for hydrologic and hydraulic modelling. Quantitative studies on the lower Niger delta have thus been limited by data availability and inaccessibility of parts of the delta (due to insecurity). Consequently, few quantitative studies using in situ data exist on the Niger delta; a quantitative study of the Niger delta by Awosika, et al., (1992) made use of aerial video data to estimate the cost of SLR and erosion losses for the Niger delta. However, subsequent studies by Ericson et al (2006), and Musa, et al., (2016) indicate that the area calculation by the study overestimated the extent of areas to be affected; thus, the value of losses might have been overestimated.

Use of satellite data helps bridge the data gap by providing ancillary data (imagery, elevation, altimetry etc.) that can be used to quantify the effects of SLR on the Niger delta. This thesis uses satellite data and other auxiliary information as the main sources of data for hydrodynamic modelling and GIS 
analysis. This is a different approach as satellite data in water management and hydrology is normally used as a last resort and not the first point of choice since such data might not have the accuracy and precision of directly measured data. Studies have however shown that innovative methodologies by scientists have enabled better exploitation of satellite data to overcome the limitations and produce results with high correlation and manageable errors within present uncertainties (Musa, Popescu, \& Mynett, A review of applications of satellite SAR, optical,altimetry and DEM data for surface water modelling, mapping and parameter estimation, 2015). This study aimed to assess the impact of SLR on the Niger delta land area, coastline, and surface water in an integrated way that will lead to practical recommendations for adaptation.

Using projected global eustatic SLR values of $19 \mathrm{~mm}$ by 2030 and $35 \mathrm{~mm}$ by 2050 in addition to subsidence, this thesis estimated that relative SLR (RSLR) for the Niger delta will range from $0.14 \mathrm{~m}-$ $0.44 \mathrm{~m}$ by 2030 , and $0.29 \mathrm{~m}-0.96 \mathrm{~m}$ by 2050 . Using this RSLR values, the results show that a rise in sea levels of $0.14 \mathrm{~m}$ already inundates areas in the Niger delta, and the flood extent increases with increase in SLR. Consequently, some 4.6-5.2\% (viz. 1119.3-1254km²) of the Niger delta land area can be lost to inundation by 2030 , and $4.9-6.8 \%$ (viz. $1175.9-1633 \mathrm{~km}^{2}$ ) by 2050 . Furthermore, the results indicate that without subsidence the inundation effect of SLR on the Niger delta will be minimal (since the eustatic values are just $19 \mathrm{~mm}$ and $35 \mathrm{~mm}$ by 2030 and 2050 respectively). Subsidence has therefore made the Niger delta very vulnerable to inundation by making the SLR values very high.

Flooding in the lower Niger River will be affected by rise in sea levels especially as the area continues to subside (chapter 4). The effects include earlier occurrence of downstream flooding, increase in water depth and flooding of areas further upstream (than would occur without SLR). This increase in in flooding will be via expansion in lateral flooding extent in the downstream areas, but flooded areas will increase upstream because higher sea levels downstream will impede downward flow of flood waters which can result in a backwater effect and subsequent flooding of areas upstream. For the years without flooding from upstream, SLR will cause coastal areas downstream of the Niger River to flood earlier than usual. More so areas upstream of the Nun River, which remain dry in normal years, will get flooded when sea levels rise.

SLR will increase the occurrence of coastal flooding (this is indicated by the flood generated by even the lowest level of rise in sea levels) because water levels and water depths will be higher (as shown for example in the Bonny River), thus increasing land area flooding extent. The flow velocity will also increase with SLR, and coastal floodwaters will thus be transported faster along the river to places upstream. Consequently, flooding of land areas at high tide will increase due to higher water levels. 
Furthermore, differences in flow velocity around narrow bends will also be higher with SLR than without, making river crossings more dangerous.

A new coastal vulnerability index called coastal vulnerability index due to SLR (CV $\mathrm{CLR}_{\mathrm{S}} \mathrm{I}$ was developed in this thesis. The $\mathrm{CV}_{\mathrm{SLR}} \mathrm{I}$ evaluates coastline vulnerability due to SLR using 17 physical, social and human influence indicators of exposure, susceptibility and resilience (Chapter 5). The results showed that the variables that make a coastline highly vulnerable to SLR include (i) physical coastal properties, (ii) human influence, (iii) social properties. The reason being that human presence influences variables like coastal infrastructure and high population density, thus increasing the probability of damage to lives and property when a disaster occurs. More so, human interventions on coastal environments can affect sediment supply and accelerate erosion, and should therefore be captured in vulnerability assessments. Besides, the location of many settlements in remote areas, far away from the local government headquarters, reduces resilience to effects of SLR. The combination of these properties make coastal segments highly vulnerable to SLR.

In conclusion, this thesis shows that parts of the Niger delta are highly vulnerable to effects of SLR due to high RSLR, and therefore need adequate mitigation/adaptation measures to protect them. Thus possible coastal mitigation/adaptation interventions for the Niger delta were modelled and studied. This thesis thus recommends that sustainable local resilience practices already being used in parts of the Niger delta should be included in adaptation planning. These include: planting of Bamboo trees for erosion control; using sandbags as bridges and dykes for flood control; using flood receptor pits as temporary flood water storage; and developing community legislation against sand mining and indiscriminate tree felling. In terms of major mitigation/adaptation interventions, measures that can be used for the lower Niger delta include: construction of dykes, by-pass channels, flood-pits (reservoirs), storm surge barriers, coastline shortening and legislation to ensure compliance by all. Furthermore, to effectively adjust to living with SLR in the Niger delta the following strategies should be adopted: building new structures raised on stilts; and changing farm practices to become more resilient. 


\section{Samenvatting}

Een versnelde toename van zeespiegelstijging is het meest belangrijke effect van klimaatverandering in kustgebieden. De laaggelegen ligging van delta's en de invloed van menselijke activiteit maken deze gebieden kwetsbaar voor de gevolgen van klimaatverandering. Om deze kwetsbaarheid te kunnen kwantificeren zijn meetgegevens nodig, die voor veel deltagebieden ontbreken. Maar als er geen adequate plannen worden gemaakt met maatregelen tegen zeespiegelstijging kan dit verstrekkende gevolgen hebben voor mensenlevens en economische bedrijvigheid. Zo wordt alleen al voor Nigeria geschat dat de schade gemakkelijk kan oplopen tot 18 miljard USD, inclusief een verlies aan kustgebied van ca. 17,000 km² (Brown et al., 2011).

De beschikbaarheid van (meet)gegevens is een van de belangrijkste factoren om kustsystemen te kunnen analyseren en modelleren. Vandaar dat het IPCC heeft aanbevolen om met name in deze gebieden gegevens te verzamelen van fysische, sociale en economische processen, waaronder topografie, landgebruik, bevolkingsdichtheid, en getijwaterstanden (Dronkers et al., 1990). Probleem is evenwel dat er met name in ontwikkelingslanden een groot gebrek is aan meetapparatuur en historische gegevens. In grote delen van Afrika ontbreken afdoende waarnemingen om hydrologisch onderzoek te doen (Niang, et al., 2014). Zo kan het lange termijngedrag van de kustlijn van Nigeria niet worden voorspeld aangezien er onvoldoende gegevens beschikbaar zijn om de veranderingen van de laatse honderd jaar te kunnen verklaren (Orupabo, 2008).

De Niger delta is het meest gevoelig voor effecten van klimaatverandering in Nigeria (de delta ligt zeer laag en heeft een heel flauwe helling) en heeft een heel laag adaptief vermogen van socioeconomische ontwikkeling in het land (FME, 2010). Er zijn betrekkelijk weinig betrouwbare gegevens om tot planvorming en beheer te komen, laat staan om hydrologische en hydraulische modellen te ontwikkelen. Studies naar de Lower Niger delta worden ook nog bemoeilijkt door de slechte toegankelijkheid van het gebied (vanwege de gevaarlijke situatie). Vandaar dat er weinig gedetailleerde studies bestaan. Awosika et al., (1992) maakte gebruik van luchtfotografie om een schatting te verkrijgen van de schade door zeespiegelstijging en erosie in de Niger delta. Vervolgstudies door Ericson et al., (2006) en Musa et al., (2016) geven aan dat deze schattingen aan de hoge kant waren en dat de schade wellicht overschat was. Door gebruik te maken van satellietwaarnemingen kan het gebrek aan in-situ meetgegevens worden opgevangen en kan toch een schatting worden gemaakt van de effecten van zeespiegelstijging in de Niger delta. 
In dit proefschrift worden satellietwaarnemingen gebruikt als de belangrijkste informatiebron voor het ontwikkelen van GIS analyses en voor het hydrodynamisch modelleren van de delta. Dit verschilt van de conventionele aanpak van hydrodynamisch modelleren waarbij satellietwaarnemingen vaak als sluitstuk worden gebruikt en niet als voorkeursbenadering, gezien de beperkte nauwkeurigheid en precisie. Inmiddels zijn er echter innovatieve methoden ontwikkeld die een beter gebruik van satellietwaarnemingen mogelijk maken met een zeer beperkte foutenmarge binnen de huidige meetnauwkeurigheid (Musa et al., 2015). Op basis hiervan is in deze studie een schatting gemaakt van de effecten van zeespiegelstijging en zijn praktische aanbevelingen gegeven voor klimaatadaptatie.

Op basis van de geschatte eustatische waarden van zeespiegelstijging van $19 \mathrm{~mm}$ in 2030 en $35 \mathrm{~mm}$ in 2050, en rekening houdend met voortgaande bodemdaling, komen de schattingen voor relatieve zeespiegelstijging in de Niger delta zoals berekend in dit proefschrift uit op $0.14 \mathrm{~m}-0.44 \mathrm{~m}$ in 2030 , en $0.29 \mathrm{~m}-0.96 \mathrm{~m}$ in 2050 . Berekeningen laten zien dat een stijging van $0.14 \mathrm{~m}$ al tot overstromingen leidt in bepaalde gebieden van de Niger delta, die steeds groter worden naarmate de stijging toeneemt. Dit heeft als gevolg dat rond 2030 ca. 4.6-5.2\% (d.w.z. 1119-1254 km2) van het land in de Niger delta verloren kan gaan door overstroming en rond 2050 zelfs 4.9-6.8\% (d.w.z. 1176-1633 km2). De berekeningen laten tevens zien dat zonder bodemdaling het effect van eustatische zeespiegelstijging slechts zeer beperkt zal zijn. Bodemdaling is daarom een belangrijke factor bij het bepalen van de kans op overstromingen in de Niger delta. Andere resultaten van deze studie zijn:

Ook in de beneden rivier van de Niger delta wordt de kans op overstroming belangrijke mate bepaald door zeespiegelstijging in combinatie met bodemdaling. Meer stroomopwaarts wordt de kans op overstroming mede beïnvloed door de stuwkromme die zich naar bovenstrooms uitbreidt omdat de uitstroom in de delta zelf beperkt wordt door zeespiegelstijging. Zelfs als de bovenstroomse rivierafvoer beperkt is, dan nog zullen de laaggelegen gebieden in de Niger delta eerder overstromen dan gewoonlijk, als gevolg van zeespiegelstijging. Datzelfde geldt voor de bovenstroomse gebieden in de Nun rivier, die bij normale afvoeren droog blijven, zullen ook eerder overstromen. Ook voor de Bonny rivier geldt dat zelfs een geringe zeespiegelstijging tot een toename van het overstromingsrisico zal leiden, zoals aangetoond in voorbeeldberekeningen. Ook de stroomsnelheden zullen toenemen, waardoor de afvoer zich sneller langs de rivier zal verplaatsen en tot hogere waterstanden zal leiden. Bij hoge getijdewaterstanden zal dan ook meer land overstromen. Een ander gevolg van hogere stroomsnelheden zal zijn dat het gevaarlijker wordt om de rivier over te steken in de vele nauwe bochten die er voorkomen. 
In dit proefschrift is een speciale index ontwikkeld die de kwetsbaarheid van kustgebieden bij zeespiegelstijging kan aangeven: de CVSLRI index. Deze wordt bepaald door 17 indicatoren voor fysische, sociale en menselijke invloeden die bepalend zijn voor de ontvankelijkheid voor en weerstand tegen overstromingen (Hoofdstuk 5). De resultaten geven aan dat de belangrijkste variabelen worden bepaald door (i) fysische eigenschappen van de kust, (ii) menselijke invloeden daarop, (iii) sociale kenmerken. Dit omdat menselijke ingrepen zoals het aanleggen van kustbescherming en bebouwing van de kuststrook, direct van invloed zijn op de kans van falen en het berokkenen van schade in geval van overstromingen. Daar komt bij dat menselijke ingrepen in de kuststrook van grote invloed kunnen zijn op het sediment transport (met name in deltagebieden) en daarmee op de stabiliteit van de kustdelta als geheel. Vandaar dat dit aspect meegenomen moet worden bij het vaststellen van de kwetsbaarheid. In geval van de Niger delta bestaan er veel kleine woongemeenschappen ver weg van lokale overheden, waardoor toezicht slechts beperkt mogelijk is. Ten gevolge hiervan zijn sommige gebieden nog extra kwetsbaar voor de gevolgen van zeespiegelstijging.

Samenvattend geldt dat in deze thesis is aangetoond dat bepaalde delen van de Niger delta bijzonder kwetsbaar zijn voor de gevolgen van zeespiegelstijging en dat adequate maatregelen voor mitigatie en adaptatie nodig zijn om deze te beschermen. Vandaar dat wordt aanbevolen om voort te bouwen op de aanwezige ervaring en bestaande praktijk bij het vaststellen van aanpassingsmaatregelen voor duurzaam kustbeheer in de Niger delta. Daartoe behoren ondermeer: het planten van bamboe struiken ten behoeve van erosiecontrole; het gebruik van zandzakken voor bruggetjes en dijkjes om overstromingen te controleren; het gebruik van kuilen voor het tijdelijk opslaan van overtollig water; het ontwikkelen van lokale voorschriften en verboden tegen het illegaal weghalen van zand en het kappen van bomen en andere vegetatie. Voor de beneden rivier van de Niger in het bijzonder gelden als belangrijkste interventiemaatregelen: het aanleggen van dijken, nevengeulen, opvangreservoirs, het aanleggen van stormvloedkeringen, verkorten van de kustlijn, alsmede wet- en regelgeving die zorgen voor naleving door alle betrokkenen. Om effectieve aanpassing aan het 'leven met zeespiegelstijging' te garanderen zouden de volgende strategieën moeten worden toegepast: nieuwe constructies verhoogd aanleggen, bijv. op palen; landbouwmethoden zodanig aanpassen dat deze meer overstromingsbestendig worden. 


\section{Table of contents}

Summary

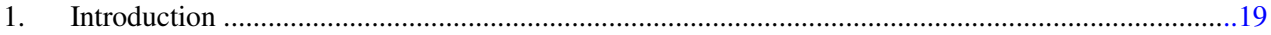

Problem statement

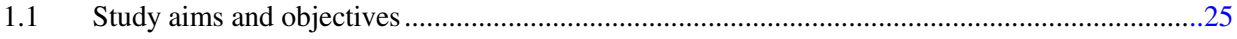

$1.2 \quad$ Scope

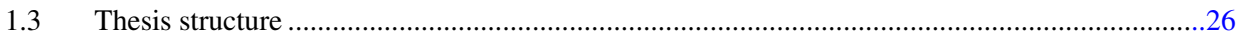

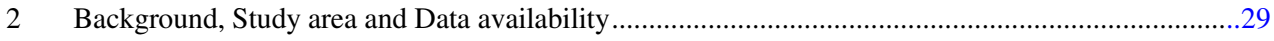

2.1 Adaptation and Mitigation strategies applied on coastal areas around the world .........................30

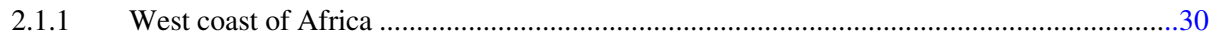

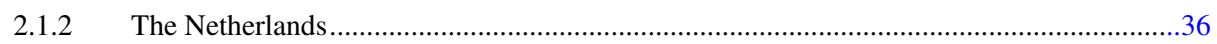

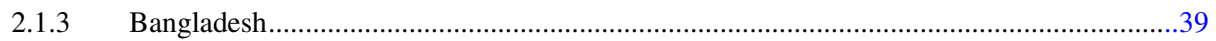

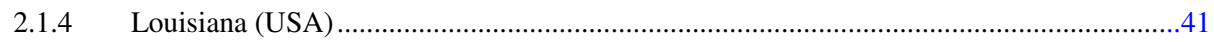

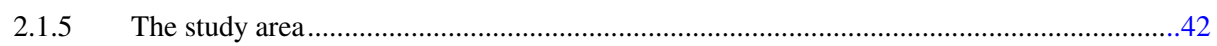

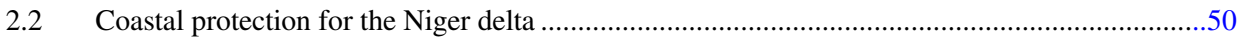

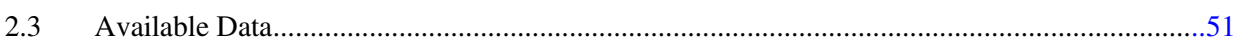

2.3.1 Measured discharge data for Lokoja upstream of the Niger delta .....................................51

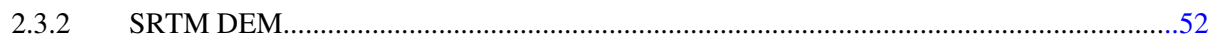

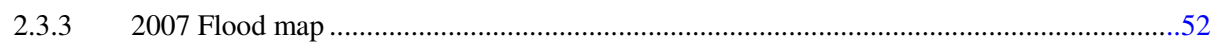

2.3.4 Shape files of: contours, state boundaries, Local Government areas, towns and settlements,

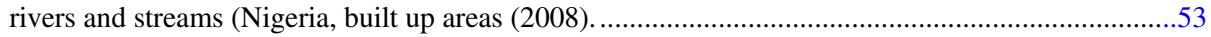

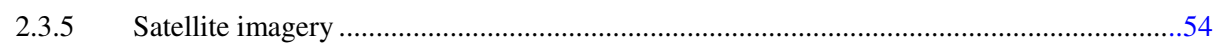

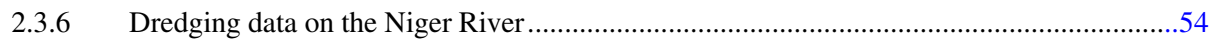

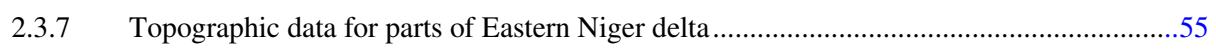

2.3.8 Niger Delta Regional Master Plan, Environment and Hydrology report.............................56

2.3.9 Socio-economic data (population, water supply/demand, available water resources) ..........57

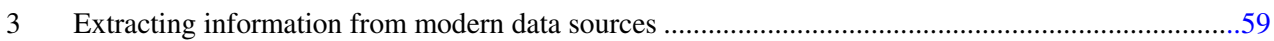

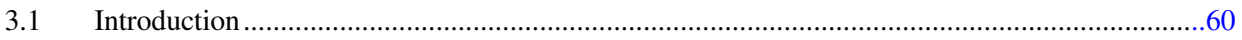

3.2 Overview of satellite data applications for surface water studies ..............................................64

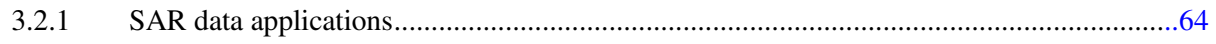

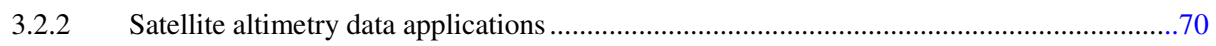

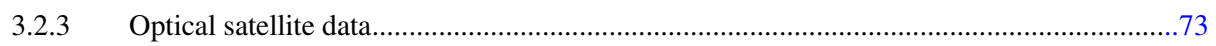

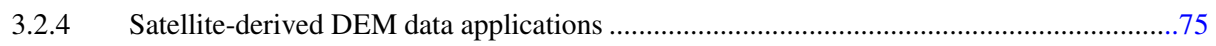

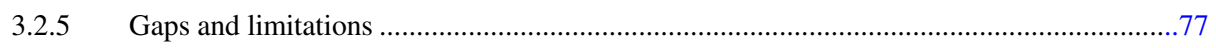

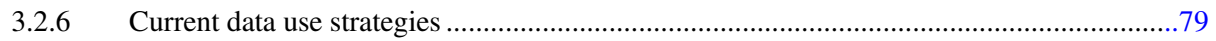

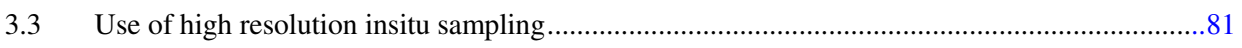

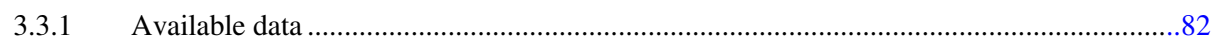

3.3.2 Utilizing dredging data for river cross section extraction and modelling ...........................83

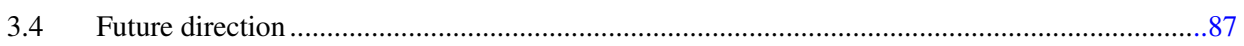

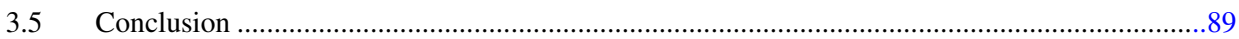


4 Modelling complex deltas in data scarce areas c .....................................................................91

4.1 Effects of river flooding on coastal areas under sea level rise conditions...............................93

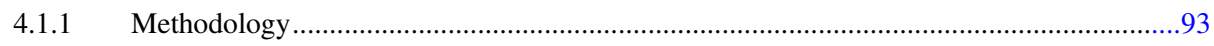

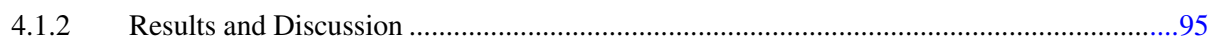

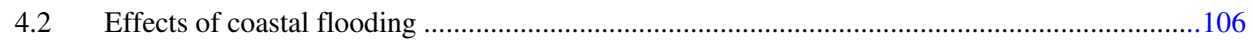

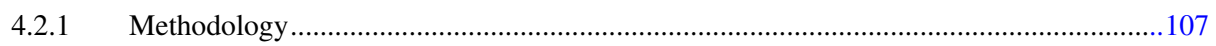

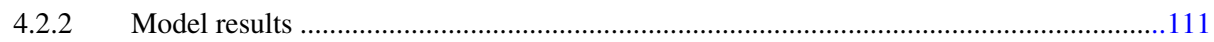

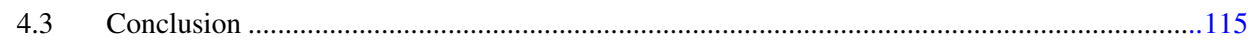

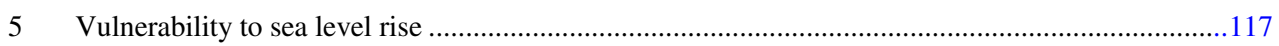

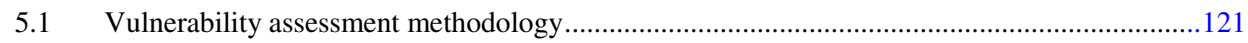

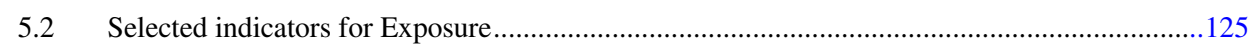

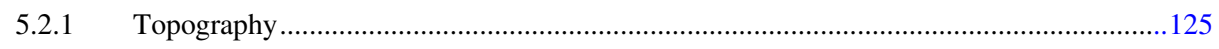

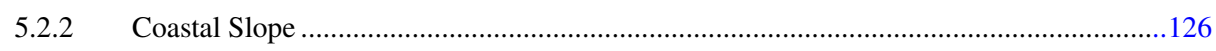

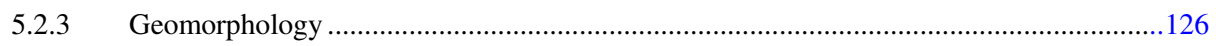

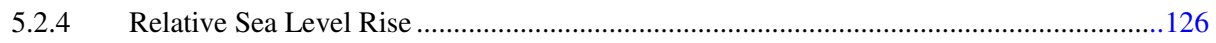

5.2.5 Annual Shoreline Erosion Rate................................................................................... 128

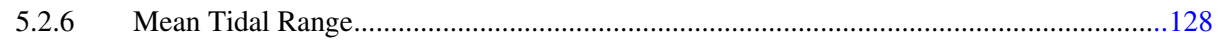

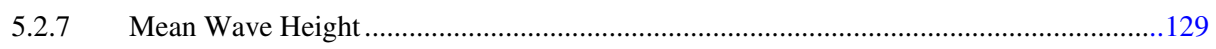

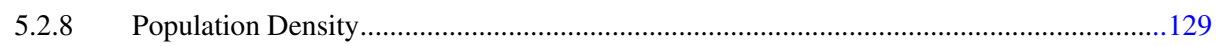

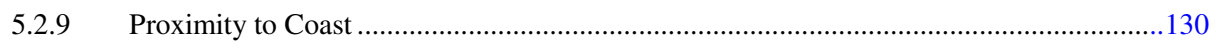

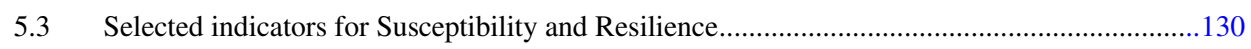

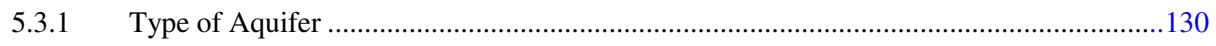

5.3.2 Aquifer Hydraulic Conductivity .............................................................................. 130

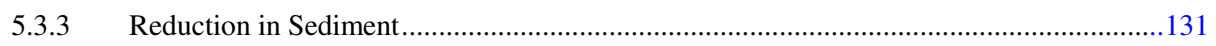

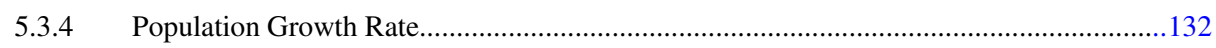

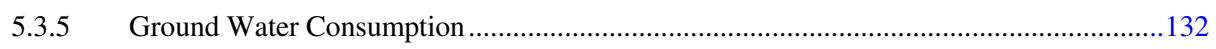

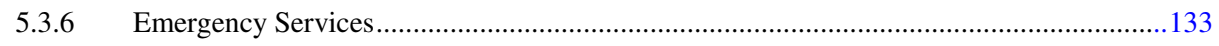

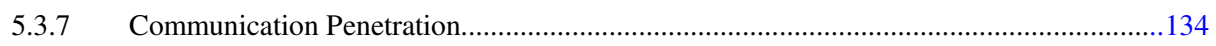

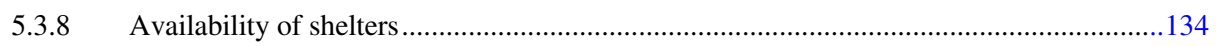

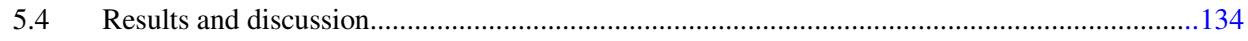

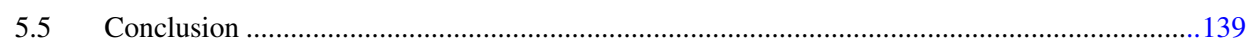

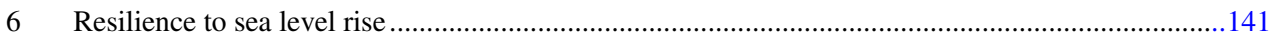

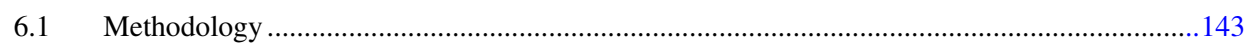

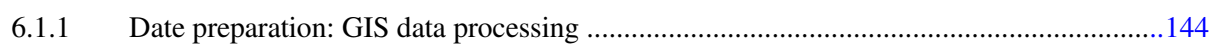

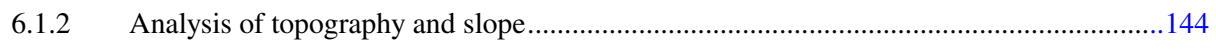

6.1.3 Mapping SLR inundation........................................................................................ 145

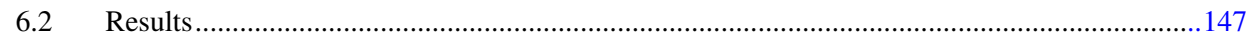

6.2.1 Local response strategies in the Niger delta........................................................... 147

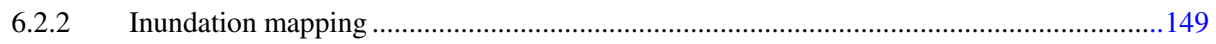

6.2.3 Physical characteristics of the Niger delta ............................................................ 151 
6.3 Discussion of results as they relate to local adaptation practices in the Niger delta .154

6.4 Conclusion 156

7 .159

7 Mitigation and adaptation to sea level rise .159

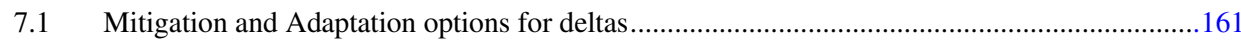

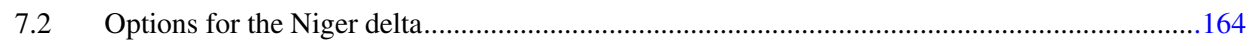

7.2.1 Scenarios for mitigation/adaptation .................................................................... 165

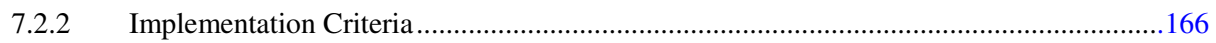

7.2.3 Coverage area and planning extent ............................................................................. 168

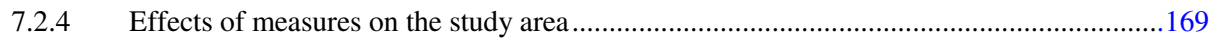

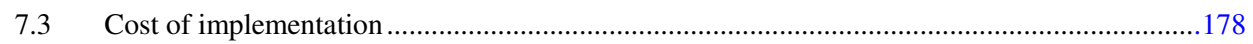

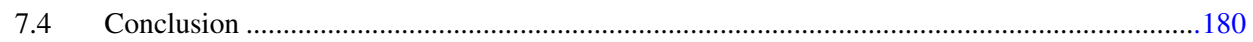

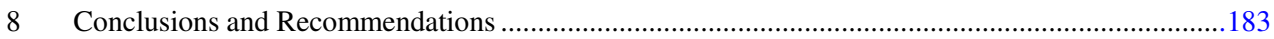

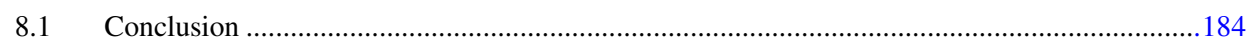

8.1.1 How can satellite data be applied in hydrological studies in delta areas?........................184

8.1.2 With recent increase in flooding, will sea level rise exacerbate the effects of river flooding?

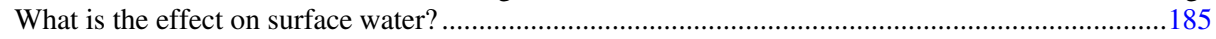

8.1.3 What is the effect of sea level rise on coastal flooding and inundation? ........................185

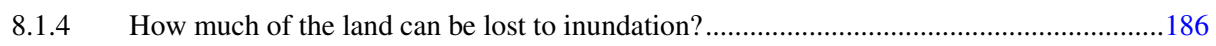

8.1.5 How can the vulnerability of deltaic coastlines to sea level rise be evaluated? ...............187

8.1.6 What should be considered in planning for SLR adaptation? Are there existing sustainable options that can be used?

8.1.7 What are the possible effects of mitigation/adaptation options on SLR impacts on the Niger delta? 188

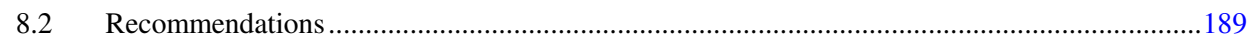

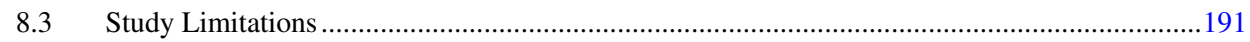

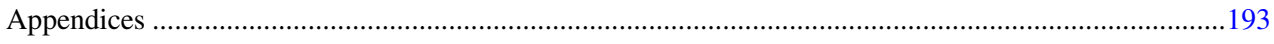

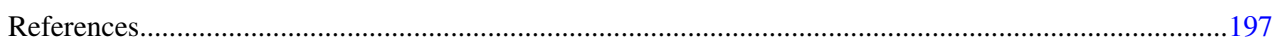

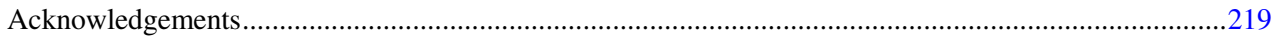

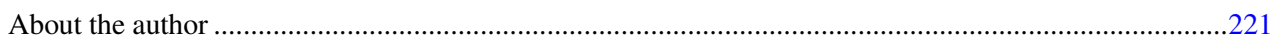




\section{1}

\section{Introduction}


Within the last few decades the atmospheric and sea surface temperatures have been rising and climates worldwide are changing (figure 1.1). Climate change has resulted from an accelerated increase in carbon dioxide and other greenhouse gas concentrations in the atmosphere (Williams \& Ismail , 2015). Increase in sea surface temperatures cause thermal expansion, which increase the water level of the sea surface (IPCC, 2013) and as a result the shoreline moves further inland. The warming of the atmosphere causes melting of mountain glaciers and polar ice sheets, thus increasing the rise in sea levels. Based on historical data eustatic sea level changes between 1950 and 2009 were on average $1.7 \mathrm{~mm} /$ year. In recent years satellite altimetry measurements (between 1993 and 2003) have shown an increase in sea level rise rates to over 3mm/year (IPCC, 2007a). Over the years scientists have used climate models to project possible sea level rise (SLR) levels for the future. These projections are based on scenarios to predict possible conditions of climate change and the states of the coastal areas. In its reports the Inter-governmental Panel on Climate Change (IPCC) had projected a rise of $0.18-0.5 \mathrm{~m}$ by the year 2100 (IPCC, 2013). This projection had its limitation due to uncertainties in response of the ice sheets, and their effect on the global sea level. Other projections of higher rise in sea level (e.g. Rahmstorf, 2007; Pfeffer, et al., 2008) were made after the IPCC (2007) report. As data became available, the IPCC revised its projections. Based on greenhouse gas emissions scenarios (known as Representative Concentration Pathways or RCPs), the IPCC projects that sea levels will rise by $0.28-0.98 \mathrm{~m}$ by the year 2100 (IPCC, 2013).

Climate change is a factor that will modify existing hazards and introduce new ones (Bogardi, Villagrán, Birkmann, \& Renaud, 2005). Natural disasters have become more frequent in coastal areas and barrier islands and river deltas are experiencing accelerated erosion, flooding and marine transgression (Williams \& Ismail , 2015). In the Mediterranean region for example, the effects of climate change observed are: decrease in the total amount of precipitation; increase in the number and intensity of extreme events such as floods and droughts; and a change in the seasonal distribution of precipitation (European Environment Agency (EEA), 2012). Along the west African coast, sea levels rise trends showed over 3mm/year from 1993 to 2010 (ESA, Space in Images: mean sea level trends, 2012).

Rise in sea levels has various consequences for low lying coastal areas such as inundation due to coastal flooding by incoming rivers and/or the sea; erosion; displacement of coastal wetlands; and inland intrusion of sea water (IPCC, 2007b; Van, et al., 2012). Furthermore, SLR 
will reduce the availability of fresh water for human consumption, and affect the fresh water habitat of fishes and other aquatic fauna and flora.

The effects of sea level rise (SLR), however, will not be uniform all over the world but will depend on the physical, socio-economical, and anthropogenic conditions of the coastal area. Consequently some areas will experience higher and more rapidly rising sea levels than others. Relative sea level rise is the change in sea levels relative to the land elevation and includes land vertical movement in addition to global sea level rise values. Relative sea level rise values are therefore higher in subsiding coasts like river deltas than the stable coastal areas.

Coastal delta landforms are formed by the combination of river flow, tides and waves; so that the dominant process determines the characteristic of the particular delta (Nicholls, Wong, Burkett, \& Codi, 2007). Fluvial deltas depend on sediment supply from upstream rivers, while Marine dominated deltas are shaped by marine processes of tide and waves. Deltas are usually very rich in biodiversity and are known to expand with increased activity upstream like agriculture and land clearing which loosen the soil adding to amount of sediment transported downstream (Mcmanus, 2002).

Some deltas like the lower Niger delta are also rich in oil and gas (and other mineral resources) making them economically very important to their countries. Coastal deltas are susceptible to subsidence when there is reduction in sediment supply (Wesselink, et al., 2015), and water or hydrocarbon extraction from underground sources (Ericson, Vorosmarty, Dingman, Ward, \& Meybeck, 2006). As hydrocarbon/water is extracted, the soil compacts to fill the void and land levels lower; as long as there is normal sediment supply and such extraction is regulated, this process might not be detrimental to the area. However where there is reduction in sediment supply to a delta, the land will subside thereby increasing residence time and reach of high tidal waters the land will subside thereby increasing residence time which can cause water logging and finally permanent inundation (Nicolls, Hoozemans, \& Marchand, 1999).

Due to different levels of land subsidence therefore, deltas record different sea level rise values than the global average value; this is known as relative seal level rise. Relative sea level rise values are usually higher in subsiding deltas because it represents the change in sea levels relative to the land elevation and includes land vertical movement in addition to global sea level rise values. 


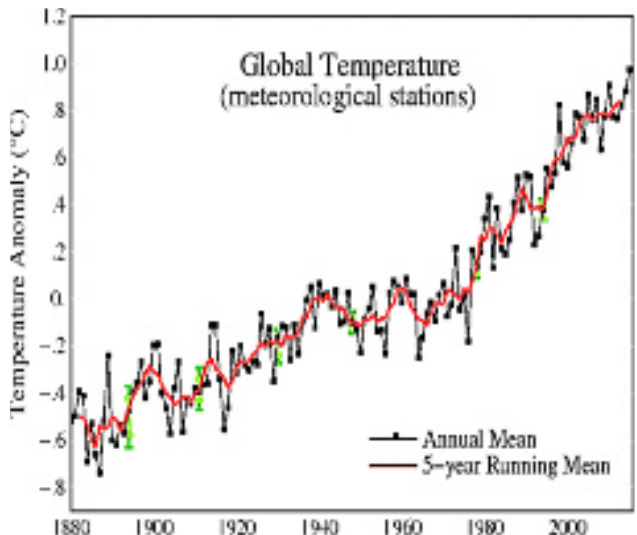

(a)

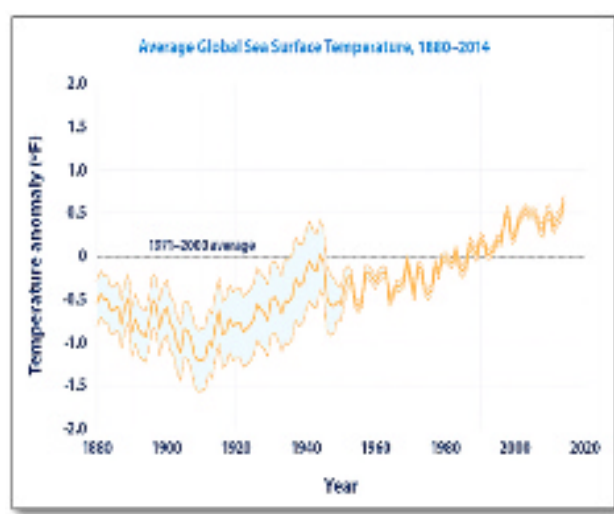

(b)

Figure 1.1. Atmospheric (a) and Sea Surface (b) temperature rise. Retrieved on 11-10-2016, from http://data.giss.nasa.gov/gistemp/graphs_v3/, and https://www.epa.gov/climate-indicators/climate-changeindicators-sea-surface-temperature

In the US, the Gulf of Mexico records a relative sea level rise between 2 - 10mm/year, and the Atlantic coast records between 2-4mm/year ( Titus, et al., 2009). Compared to other coastal areas, river deltas have complex morphologies, because river waters and sediments are transported through the deltas into the sea. A delta can have many elements included, such as barrier islands, multiple estuaries, sand beaches, or mud coasts. It can be crisscrossed by rivers emanating from different sources and carrying different types of sediments; which differentiate the segments of the coast.

\section{Problem statement}

In preparation for consequences of SLR, the IPCC recommended that coastal areas collect data on physical, social and economic parameters e.g. topographical, land-use, population, tidal wave and range (Dronkers, et al., 1990). The physical properties of deltas and anthropogenic activities make them vulnerable to the effects of the changing climate; however when evaluation of vulnerabilities is important many coastal deltas lack necessary data (e.g. water level) for performing such a task. Data availability is one of the most important factors for analysis, assessment and modelling of physical and other phenomena related to river and coastal systems. Many developing countries however lack measuring equipment and long term records; Africa generally lacks long-term observational data to aid hydrological research 
(Niang, et al., 2014). In well-developed coastal areas such as The Netherlands, measurements and records of hydrologic properties are kept, adequate provision is made for drainage of rain rainwater, river flows and groundwater, and coastal defences are built against storm surges and SLR (Wesselink, et al., 2015).

Leaving coastal areas without adequate plans to combat sea level rise will cost vulnerable areas huge amounts of losses in lives and properties; e.g. in Nigeria alone, a no-response scenario will cost over $\$ 18$ billion in losses, including an estimated $17,000 \mathrm{~km}^{2}$ of wetland (Brown, Kebede, \& Nicolls, 2011). It is therefore imperative to study the level of vulnerability of coastal areas to the effects of SLR like flooding, inundation, erosion, loss of wetlands and salinitization of underground water sources even if data availability is scarce. Sea level data and information are strategic for planning and management of coastal areas, however many developing countries lack measuring equipment and long term records. Long-term shoreline dynamics of the Nigerian coastline for instance cannot be predicted as available data is insufficient to even explain fluctuations in the last hundred years (Orupabo, 2008). The lower Niger delta (figure 1.2) is thus one of the coastal areas with little data for coastal planning and management. Consequently, it has poor availability of data for hydrologic and hydraulic modelling.

The Niger delta has the highest sensitivity to climate change in Nigeria, and its adaptive capacity is the second lowest in terms of socio-economic development of the country (FME, 2010). It is one of the vulnerable coastal areas in the world due to its natural properties: a very low elevation and gentle slope. With an anticipated rise in sea levels of $0.5-1 \mathrm{~m}$ for the Nigerian coast by 2100 (FME, 2010), large parts of the delta could be affected; with huge costs in both lives and property. Based on physical properties and human population to be displaced, studies by (Brooks, Nicolls, \& Hall, 2006) and Ericson, et al., (2006), rank the Niger delta among the vulnerable coasts of the world. Many articles have been written and studies carried out on the possible effects of climate change and sea level rise on the coastal zone of Nigeria (Akinro, Opeyemi, \& Ologunaba, 2008; Ogba \& Utang, 2007; Awosika, French, Nicolls, \& Ibe, 1992); many of these include response strategies and give possible mitigation methods to reduce any negative effects on the land and livelihood of the communities. However a look at the available literature shows that most studies are based on the general Nigerian coast with more emphasis on the Lagos coastal area. Few quantitative studies using insitu data exist on the Niger delta. A quantitative study of the Niger delta by Awosika, et al., (1992) made use of aerial video data to estimate the cost of SLR and erosion losses for the Niger delta. Subsequent studies by 
Ericson et al (2006), and Musa, et al., (2016) indicate that the area calculation by the study overestimated the extent of areas to be affected thus the value of loss might have also been over estimated.

Quantitative studies on the lower Niger delta have been limited by data availability and inaccessibility of parts of the delta (due to insecurity). Use of satellite data helps bridge this gap by providing ancillary data (imagery, elevation, altimetry etc.) that can be used to quantify the effects of SLR on the Niger delta. Satellite remote sensing provides a source of hydrological data that is unhindered by geopolitical boundaries, has access to remote/unreachable areas, and provides frequent and reliable data (Jung, et al., 2010). Use of satellite data to estimate hydrological parameters continues to increase due to greater availability of satellite data, improvement in knowledge of and utilization of satellite data, as well as expansion of research topics. A very important catalyst to this growth in satellite data utilization is the ability to use it in a GIS environment. GIS enables comparison and deduction of relationships that exist amongst the complex data sources used for analysis. Thus relationships like the effects of landuse change on surrounding water bodies or water management are easily analysed and depicted. Consequently, satellite data is commonly used for: mapping of water bodies, testing of inundation models, soil moisture measurements, precipitation monitoring, estimation of evapo - transpiration, and mapping of flood extent.

Satellite data have been used for change assessment studies of the Niger delta (Twmasi \& Merem, 2006; Ogoro, 2014), flood/erosion extent documentation and mapping (Ehiorobo \& Izinyon, 2011; Eyers \& Obowu, 2013). Flood inundation estimates for the Niger delta are based on GIS depictions of flooding extends from static overflowing of water on GIS layers; a method that generally over estimates the coverage area of flood waters and does not take loss through local drainage/runoff into account (e.g. Akinro, et al., 2008). This thesis uses satellite data and other ancillary information as the main sources of data for modelling and analysis. This is a different approach as satellite data in water management and hydrology is normally used as a last resort and not the first point of choice since such data might not have the accuracy and precision of directly measured data. However over time, innovative methodologies by scientists have enabled better exploitation of satellite data to overcome the limitations and produce results with high correlation and manageable errors; within present uncertainties (Musa, Popescu, \& Mynett, A review of applications of satellite SAR, optical,altimetry and DEM data for surface water modelling, mapping and parameter estimation, 2015). 


\subsection{Study aims and objectives}

The study has the general aim of assessing the impact of SLR on the Niger delta land area, coastline, and surface water in an integrated way that will lead to practical recommendations for adaptation.

The specific objectives will use satellite based data and spatial information to:

- Model the impact of SLR for Niger delta land areas, major rivers and coastlines.

- Create scenarios and run hydrodynamic models of effect of SLR on flooding from surface water.

- Measure and map sea level rise inundation extents based on topography and tidal variability.

- Identify and map the most vulnerable parts of the Niger delta coastline to SLR.

- Create adaptation scenarios for the Niger delta, and estimate the effect of each scenario implementation.

Fulfilling the objectives of the thesis should answer the following questions:

1. How can satellite data be applied in hydrological studies in delta areas?

2. With recent increase in flooding will sea level rise exacerbate the effects of river flooding? What is the effect on surface water?

3. What is the effect of SLR on coastal flooding and inundation?

4. How much of the land that can be lost to inundation?

5. How can the vulnerability of deltaic coastlines to sea level rise be evaluated?

6. What should be considered in planning for SLR adaptation? Are there existing sustainable options that can be used?

7. What are the possible effects of the mitigation/adaptation options on SLR impacts on the Niger delta?

\subsection{Scope}

The study covers the geomorphologic Niger delta area spanning from Jalla in Ondo on the west to Bonny on the east (Fig. 1.2). The vulnerability assessment is limited to the parts of the Niger 
delta directly connected to the ocean and inland up to $45 \mathrm{~km}$; it does not include the entire political Niger delta as defined by the Nigerian government. The modelling aspect of the methodology only addresses issues concerning river flooding from the Niger River and excludes the following: flooding from other rivers within the area, rainfall/ runoff and other effects of the broad concept of climate change.

\subsection{Thesis structure}

The thesis is made of eight chapters structured to answer the research questions posed and fulfil the aims and objectives of the research.

Chapter 1: This introductory chapter presents the problem with the study area, and the existing gaps that created the need for the methodology used in the thesis (to solve the problem). The research questions, aims and objectives are also presented herein.

Chapter 2: The second chapter gives the background information on climate change induced sea level rise and its consequences for low-lying delta areas. The study area is described; its physical properties (slope, geomorphology, topography, aquifers etc.), hydrology, as well as the changes it is already undergoing that can be exacerbated by sea level rise. The available data used for the research are also described and their sources mentioned.

Chapter 3: In view of data scarcity, this chapter discusses how advanced data sources are used for surface water and coastal area studies; for modelling, mapping and parameter estimations. Use of high resolution insitu dredging data for river cross section estimation (for flood modelling) is also discussed.

Chapter 4: Using non-conventional data, the effects of sea level rise on river and coastal flooding are modelled, and the results presented in this chapter. The modelling objectives, data used, methodology, model setup, scenarios, and constraints are explained. The implications of sea level rise on flooding extent, water depth, and flood velocity are discussed.

Chapter 5: In this chapter the vulnerability of the Niger delta coastline to sea level rise is calculated based on seventeen physical, social and human influence variables; obtained from both conventional and advanced data sources. The variables are which divided into exposure, susceptibility and resilience variables, are used in a new methodology called the 'Coastal Vulnerability to sea level rise Index' ( $\left.\mathrm{CV}_{\text {SLR }} \mathrm{I}\right)$ that combines the 'Coastal Vulnerability Index' 
(CVI) with the 'Flood Vulnerability Index' (FVI). The advantages and disadvantages of the new index are discussed.

Figure 1.2. The lower Niger delta Nigeria, West Africa. SRTM DEM showing the topography of the area is

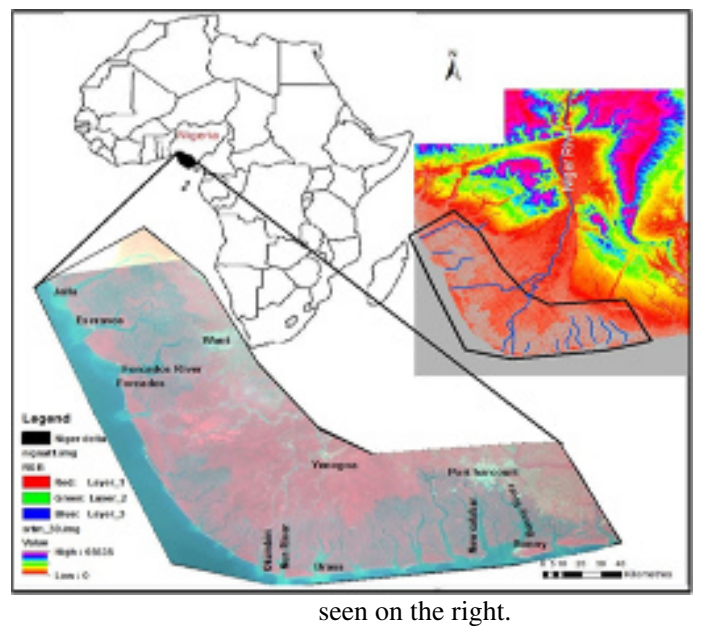

Chapter 6: This chapter discusses the importance of considering the people's resilience when planning for sea level rise adaptation or mitigation. It considers the sustainability of local resilience practices (against flooding, erosion, etc.) already familiar to the people in a 'business as usual' scenario. A GIS based mapping of sea level rise inundation by 2030 and 2050 is also included.

Chapter 7: In this chapter, adaptation scenarios, possible options they entail, and the implications of each for delta areas are discussed and applied to the Niger delta. The effects on flooding /inundation extent, river water level/depth, and velocity are presented. A rough estimate of the cost of measures applied is also included.

Chapter 8: This chapter compiles the conclusions reached at each stage of the research. It discusses the research questions vis-à-vis the answers obtained within the thesis and makes recommendations where applicable. The limitations of the study and its constraints (based on assumptions made in applying the methodology), are also included.

Appendix: This is made up of two sections A, and B. Appendix A shows how SRTM compares with 40m contour data of Nigeria (using RMSE as accuracy measure). Appendix B shows results of river flood modelling for rivers Forcados and Nun. 


\section{References}

Abam, T. (2001). Regional hydroiogical research perspectives in the Niger Delta. Hydrological Sciences , 46(1). Retrieved from http://hydrologie.org/hsj/460/hysj_46_01_0013.pdf

Adaramola, M. , Oyewola, M. , Ohunakin, O. , \& Akinnawonu, O. (2014). Performance evaluation of wind turbines for energy generation in Niger Delta. Nigeria. Sustainable Energy Technologies and

Assessments , 6 (2014), 75-85. doi:dx.doi.org/10.1016/j.seta.2014.01.001.

Agabi, C. (2013). Nigeria: 40km of Niger-Delta Land May Be Extinct in 20 Years - Don . Retrieved April

29th, 2016, from http://mangroveactionproject.org/nigeria-40km-of-niger-delta-land-may-be-extinct-in-20years-don/

Aich, V. , Liersch, S. , Vetter, T., Huang, S. , Tecklenburg, J. , Hoffmann, P. , \& Hattermann, F. (2014). Comparing impacts of climate change on streamflow in four large African river basins. Hydrology and Earth System Sciences , 18 1305-1321, 2014. doi:doi:10.5194/hess-18-1305-2014.

Akinro, A. , Opeyemi, D. , \& Ologunaba, I. (2008). Climate change and environmental degradation in the Riger delta region of nigeria: its vulnerability, impacts and possible mitigation. Research Journal of Applied Sciences , 3 (3), 167-173.

All science fair projects . (2015). Sea water and its effects on Bambusa vulgaris (common bamboo). Retrieved January 07, 2016, from http://www.all-science-fair-projects.com/print_project_1073_120 Alwang, J. , Siegel, P. , \& Jorgensen, S. (2001). Vulnerability a view from different disciplines . Washington DC: World Bank . Retrieved from http://documents.worldbank.org/curated/en/2001/06/1637776/vulnerability-view-different-disciplines . Appiah, S. (2016). Prez Mahama directs extension of Keta sea defence project to cover more communities . Retrieved February 20, 2017, from Graphic Online:

http://www.graphic.com.gh/news/general-news/prez-mahama-directs-extension-of-keta-sea-defenceproject-to-cover-more-communities.html

Awosika, L. , \& Folorunsho, R. (2012). Nigeria . Retrieved from ODINAFRICA: http://www.odinafrica.org/nigeria

Bachmair, F. , Calderon, S. , Clarke, K. , Davies, A., Davaadorj, K. , Jenkins, P., Shearer, K. (2012). Climate Change Adaptation Capstone workshop .Concept paper: The Niger Delta. Spring 2012.

Columbia : Columbia SIPA.

Bacon, P. (1996). Wetlands and Biodiversity. In A. Hails (Ed.), Wetlands, biodiversity and the Ramsar convention: the role of the convention on wetlands in the conservation and wise use of biodiversity (p. 17). Gland: Ramsar Convention Bureau. Retrieved from Wetlands: cradle of species diversity .

Baird: Oceans, Lakes and Rivers. (2011). Keta Coastal Defence . Retrieved February 20, 2017, from http://www.baird.com/what-we-do/project/keta-coastal-defence

Balica, S. F. , Douben, N. , \& Wright, N. G. (2009). Flood Vulnerability Indices at Different Spatial Scales. water science and technology .

Balica, S. , Popescu, I. , Beevers, L. , \& Wright, N. (2013). Parametric and physically based modelling techniques for flood risk and vulnerability assessment: a comparison. Journal of Environmental Modelling and Software , 3 (41), 84-92.

Bariweni, P. , Tawari, C. , \& Abowei, J. (2012). Some Environmental Effects of Flooding in the Niger Delta Region of Nigeria. International Journal of Fisheries and Aquatic Sciences , 1 (1), 35-46.

Barneveld, H. , Silander, J. , Sane, M. , \& Malnes, E. (2008). Application of satellite data for improved flood forecasting and mapping. 4th International Symposium on Flood Defence:Managing Flood Risk, Reliability and Vulnerability Toronto, Ontario, Canada, May 6-8, 2008 . Toronto, Canada. Retrieved May 31, 2015, from

http://www.hkv.nl/site/hkv/upload/publication/Application_of_satellite_data_for_improved_flood_forecastin g_HJB.pdf

Belaud, G. , Cassan, L. , \& Bader, J. C. (2010). Calibration of a propagation model in large river using satellite. In A. I. Stamou (Ed.), 6th International Symposium on Environmental Hydraulics (pp. 869-874). Athens, Greece: CRC PRESS. Environmental Hydraulics.

Bercher, N. , Calmant, S. , Picot, N. , Seyler, F. , \& Fleury, S. (2014, 04 03). Evaluation of cryosat-2 measurements for the monitoring of large river water levels. Retrieved 06 25, 2015, from Along-

Track.com: http://chronos.altihydrolab.fr/2012-09-

23\%20Venice\%20ESA\%2020\%20years\%20of\%20progress\%20in\%20altimetry/Bercher.2012b\%20(Venic e\%20Paper)\%20CryoSat-2\%20hydro.pdf

Bhattacharya, B. , Shams, M. , \& Popescu, I. (2013). On the influence of bed forms on flood levels.

Environmental Engineering Management , 12, 857-863.

Bierbaum, R. , Smith, J. , Lee, A. , Blair, M. , Carter, L. , Stuart Chapin III F. , Verduzco, L. , (2013). A comprehensive review of climate adaptation in the United States: more than before, but less than needed. Mitigation Adaptation Strategy Global Change , 18 , 361-406. doi:10.1007/s11027-012-9423-1. 
Birkmann, J. (2007). Risk and vulnerability indicators at different scales:Applicability, usefulness and policy implications. Environmental Hazards , 20-31.

Bogardi, J. , Villagran, J. , Birkmann, J. , \& Renaud, F. (2005). Vulnerability in the context of Climate Change. Human security and climate change, (p. 14). Asker near Oslo. Retrieved January 12, 2016 Brakenridge, G. , Kettner, A. , Slayback, D. , \& Policelli, F. (2007). 01 23). The Surface Water data record: Dartmouth Flood Observatory . Retrieved from Dartmouth Flood Observatory:

http://floodobservatory.colorado.edu/Version3/000E010Nv3.html .

Briggs, N. , Okowa, W. , \& Ndimele, O.-M. (2013). The economic development of Rivers State . Port Harcourt: River State economic advisory council. Retrieved August 17, 2015

Brooks, N. (2003). Vulnerability, risk and adaptation: A conceptual framework. Norwich, UK: Tyndall Centre for Climate Change Research. Retrieved from

https://pdfs.semanticscholar.org/750a/8ad7921ba82db2f6395d3dec379355ac45cf.pdf.

Brooks, N. , Nicolls, R. , \& Hall, J. (2006). Sea Level Rise Coastal Impacts and Responses . Retrieved 09 18, 2012, from WBGU: www.wbgu.de/wbgu_sn2006.html

Brown, S. , Kebede, A. , \& Nicolls, R. (2011). Sea-Level Rise and Impacts in Africa, 2000 to 2100 . UNEP. Retrieved November 16, 2015, from

http://www.unep.org/climatechange/adaptation/Portals/133/documents/AdaptCost/9\%20Sea\%20Level\%2 ORise\%20Report\%20Jan\%202010.pdf

Buytaert, W. , Dewul, A. , De Bievre, B. , Clark, J. , \& Hannah, D. (2016). Citizen Science for Water Resources Management: Toward Polycentric Monitoring and Governance? Journal of Water Resources Planning and Management , 01816002-1-4. doi: 10.1061/(ASCE)WR.1943- 5452.0000641

Buytaert, W. , Zulkafli, Z. , Grainger, C. , Acosta, L. , Alemie, T. , Bastiaensen, J. , \& Zhumanova, M. (2014). Citeizen science in hydrology and water resources: opportunities for knowledge generation, ecosystem service management, and sustainable development. Frontiers in Earth Science , 2(26), 1-21. doi:doi: 10.3389/feart.2014.00026.

Canadian Space Agency (CSA) . (2015, 05 21). RADARSAT Constellation . Retrieved June 23, 2015, from RADARSAT constellation: http://www.asc-csa.gc.ca/eng/satellites/radarsat/

Cardno, C. (2016). Massive flood protection project under way in bangladesh . Retrieved January 29, 2017, from Civil Engineering: The Magazine Of The American Society Of Civil Engineers :

http://www.asce.org/magazine/20150203-massive-flood-protection-project-under-way-in- bangladesh/ Castro-Gama, M. , Popescu, I. , Li, S. , \& Mynett, A. (2014). Flood inference simulation using surrogate modelling for the Yellow River multiple reservoir system. Environmental Modelling and Software , 55 , 250-265.

Chen, H. , Yang, D. , Hong, Y. , Gourley, J. , \& Zhang, Y. (2013). Hydrological data assimilation with the Ensemble Square-Root-Filter: Use of streamflow observations to update model states for real-time flash flood forecasting. Advances in Water Resources , 59 , 209-220. doi:10.1016/j.advwatres.2013.06.010. Chow, V. T. (1959). Open Channel Hydraulics . Singapre: mcgraw-Hill, international edition 1973. CIESIN . (2013, Januray 4). Sea Level Rise Impacts on Ramsar Wetlands of International Importance. (NASA Socioeconomic Data and Applications Center (SEDAC)) Retrieved January 13(2016). from State of the planet: Earth institute, Center for International Earth Science Information Network. Columbia University. columbia University:,. doi:10.7927/H4CCOXMD.

CNES . (2016). AVISO+. Retrieved November 22, 2016, from

http://www.aviso.altimetry.fr/en/missions/future-missions/jason-cs.html

Cretaux, J. F. , Stephane, C. , Romanovski, V. , Shabunin, A. , Lyard, F. , Berge Nguyen, M. , \& Perosanz, F. (2009). An absolute calibration site for radar altimeters in the continental domain : lake Issykkul in Central Asia. Journal of Geodesy , 83 (8), 723-735.

Cretaux, J. , Berge-Nguyen, M. , Leblanc, M. , Del Rio, R. A. , Delclaux, F. , Mognard, N. , .. . Maisongrande, P. (2011). Flood mapping inferred from remote sensing data. Fifteenth International Water Technology Conference. Alexandria, Egypt.

Cutter, S. L. , Emrich, C. T. , Webb, J. J. , \& Morath, D. (2009). Social Vulnerability to ClimateVariability Hazards: A Review of the Literature. South Carolina, USA: Hazards and vulnerability research institute . Retrieved from http://adapt.oxfamamerica.org/resources/Literature_Review.pdf .

Cutter, S. , Barnes, L. , Berry, M. , Burton, C. , Elijah, E. , Evans, E. , \& Webb, J. (2008). A place-based model for understanding community resilience to natural disasters. Global Environmental Change , 18 (4), 598-606. doi:doi.org/10.1016/j.gloenvcha.2008.07.013.

Danquah, J. , Attippoe, J.-A. , \& Ankrah, J. (2014). Assessment of residential satisfaction in the resettlement towns of the keta basin in Ghana. International Journal Civil Engineering, Construction and Estate Management , 2 (3), 26-45 . Retrieved from http://www.eajournals.org/wpcontent/uploads/Assessment-Of-Residential-Satisfaction-In-The-Resettlement-Towns-Of-The-Keta-BasinIn-Ghana.pdf. 
Dasgupta, e. a. (2009). Climate Change and the future impacts of Storm Surge disasters in developing countries . Centre for global dvelopment.

Dellepiane, S. , de Laurentiis, R. , \& Giordano, F. (2004). Coastline Extraction from SAR Images and a Method for the Evaluation of the Coastline Precision. Pattern Recognition Letters , $25,1461-1470$.

Deltares . (2013, April). Sobek 1D/2D modelling suite for integral water solutions. User manual , pp. 491500.

Deltares (2016). 01 22). D-Flow user manual . Retrieved from: .

http://content.oss.deltares.nl/Delft3d/manuals/D-Flow_FM_User_Manual.pdf.

Di Baldassarre, G. , Schumann, G. , \& Bates, P. D. (2009). A technique for the calibration of hydraulic

models using uncertain satellite observations of flood extent. Journal of Hydrology , 367 (3-4), 276-282. doi:10.1016/j.jhydrol.2009.01.020.

Dinh, Q. , Balica, S. , Popescu, I. , \& Jonoski, A. (2012). Climate change impact on flood hazard, vulnerability and risk of the Long Xuyen Quadrangle in the Mekong Delta. International Journal of River Basin Management , 10 (1), 103-120. doi:dx.doi.org/10.1080/15715124.2012.663383.

DLR . (2015). Earth Observation: TanDEM-X - the Earth in three dimensions . Retrieved June 01, 2015, from http://www.dlr.de/dlr/en/desktopdefault.aspx/tabid-10378/566_read-426/\#/gallery/345

DPIPWE . (2012). Confined and Unconfined aquifers . Retrieved 03 01, 2013, from

http://www.dpipwe.tas.gov.au/inter.nsf/WebPages/JMUY-4Z5262?open

Dronkers, J. , Gilbert, J. , Butler, L. , Carey, J. , Campbell, J. , James, E. , . . von Dadelszen, J. (1990).

Strategies for adaption to sea level rise. Report of the IPCC Coastal Zone Management Subgroup:

Intergovernmental Panel on Climate Change. Geneva: IPCC. Retrieved from

http://papers.risingsea.net/federal_reports/IPCC-1990-adaption-to-sea-level-rise.pdf

Duan, Z. \& Bastiaanssen, W. (2013). Estimating water volume variations in lakes and reservoirs from four operational satellite altimetry databases and satellite imagery data. Remote Sensing of Environment , 134, 403-416. doi:10.1016/j.rse.2013.03.010.

Dwarakish, G. S. , Vinay, S. A. , Natesan, U., Asano, T., Kakinuma, T. , Venkataramana, K. , \& Babita, M. K. (2009). Coastal vulnerability assessment of the future sea level rise in Udupi coastal zone of Karnataka state, west coast of India. Ocean and Coastal management , 52, 467478. doi:doi:

10.1016/j.ocecoaman.2009.07.007.

Ehiorobo, J. , \& Izinyon, O. (2011). Measurements and Documentation for Flood and Erosion Monitoring and Control in the Niger Delta States of Nigeria. FIG Working Week 2011 . Marrakech, Morocco: FIG Working Week 2011. Retrieved 08 08, 2016

El-Rabbany, A. (2002). Introduction to GPS: the global positioning system . Norwood MA: ARTECH HOUSE INC.

Emiedafe, W. (2015). 8 Mega Construction Projects in Nigeria . Retrieved March 13, 2017, from http://sapientvendors.com.ng/8-mega-construction-projects-in-nigeria/

Epete, B. (2012). The flow pattern of the bonny and new calabar river systems of niger delta region, Nigeria. FIG.NET. Retrieved from FIG Working Week 2012 - Territory, environment, and cultural heritage: https://www.fig.net/resources/proceedings/fig_proceedings

/fig2012/ppt/ts07g/TS07G_ekpete_5516_ppt.pdf

Ericson, J. , Vorosmarty, C. , Dingman, S. , Ward, L. , \& Meybeck, M. (2006). Effective sea level rise and deltas: causes of change and human dimension implications. Journal of Planetary Change , 63-82.

ESA . (2012). Space in Images: mean sea level trends . Retrieved November 16, 2016, from European Space Agency: http://www.esa.int/spaceinimages/Images/2012/09/Mean_sea_level_trends

ESA . (2015). Sentinel 3 . Retrieved June 15, 2015, from Copernicus, observing the Earth:

http://www.esa.int/Our_Activities/Observing_the_Earth/Copernicus/Sentinel-3

ESRI . (2016). ArcGIS. Retrieved 01 06, 2016, from http://www.esri.com/software/arcgis/capabilities

European commission . (2012). Integrated Coastal Zone Management. Our coast: outcomes and lessons learnt (2012 ed.). ( R. Steijn , P. Czerniak , A. Volckaert , M. Ferreira , E. Devilee , T. Huizer , \& R. ter Hofstede, Trans.) Luxembourg : Publications Office of the European Union. doi: 10.2779/9345

Eyers, R. , \& Obowu, C. (2013). Niger Delta Flooding: Monitoring, Forecasting \& Emergency Response Support from SPDC. Abuja, Nigeria, 6 - 10 May 2013: FIG Working week 2013. Retrieved 08 16, 2016 Ezer, T. \& Liu, H. (2010). On the dynamics and morphology of extensive tidal mudflats: Integrating remote sensing data with an inundation model of Cook Inlet. Alaska. Ocean Dynamics , 60 (5), 1307-1318.

doi:10.1007/s10236-010-0319-x.

FME (2010). National Environmental, Economic and Development Study (NEEDS) for climate change in Nigeria . Federal Ministry of Environment (Special climate change unit): Retrieved from. https://unfccc.int/files/adaptation/application/pdf/nigerianeeds.pdf.

Fohringer, +J. , Dransch, D. , Kreibich, H. , \& Schroter, K. (2015). Social media as an information source for rapid flood inundation mapping. Natural Hazards and Earth Systems Sciences (NHESS) , 15 , 2725- 
2738. doi:10.5194/nhess-15-2725-2015

Fraser, C. S. , \& Ravanbakhsh, M. (2011). Performance of DEM generation technologies in coastal environments. 7th International Symposium on Digital Earth . Perth, Australia.

French, T. (2016). About Tech: What is Microsoft Excel and What Would I Use it for? Retrieved 07 17, 2016, from http://spreadsheets.about.com/od/excelformulas/ss/What-is-Microsoft-Excel- and-WhatWould-I-Use-it-for.htm

Fu, C. , Popescu, I. , Wang, C. , \& Mynett, A. (2014). Challenges in modelling river flow and ice regime on the Ningxia-Inner Mongolia reach of the Yellow River, China. Hydrology and Earth Systems Sciences , 18 , 1225-1237. doi:doi:10.5194/hess-18-1225-2014.

Garcia-Pintado, J. , Mason, D. , Dance, S. , Cloke, H. , Neal, J. , Freer, J. , \& Bates, P. (2015). Satellitesupported flood forecasting in river networks: A real case study. Journal of Hydrology , 523, 706-724. doi:10.1016/j.jhydrol.2015.01.084.

Getirana, A. C. , Bonnet, M.-P. , Calmant, S., Roux, E. , Rotunno Filho, O. C. , \& Mansur, W. J. (2009). Hydrological monitoring of poorly gauged basins based on rainfall-runoff. Journal of Hydrology , 379 , 205-219. doi:0.1016/j.jhydrol.2009.09.049.

Giustarini, L. , Matgen, P. , Hostache, R. , Montanari, M. , Plaza, D. , Pauwels, V. , \& Savenije, H. (2011). Assimilating SAR-derived water level data into a hydraulic model:a case study. Hydrology and Earth System Sciences , 15 , 2349-2365. doi:10.5194/hess-15-2349-2011.

Good, S. , Mallia, D. , Lin, J. , \& Bowen, G. (2014). Stable Isotope Analysis of Precipitation Samples Obtained via Crowdsourcing Reveals the SpatiotemporaL Evolution of Superstorm Sandy. PLOS ONE , 9 (3), 1-7. doi:doi:10.1371/journal.pone.0091117.

Gornitz, V. , Couch, S. , \& Hartig, E. (2001). Impacts of sea level rise in the new york city metropolitan area. Global and planetary change , 32 (1), 61-88.

Gornitz, V. , White, T. , \& Cushman, R. (1991). Vulnerability of the U.S. to future sea-level rise. Seventh Symposium on Coastal and Ocean Management, (pp. 2354-2368). Long Beach, CA(USA).

Gorokhovich, Y. \& Voustianiouk, A. (2006). Accuracy assessment of the processed SRTM-based elevation data by CGIAR using field data from USA and Thailand and its relation to the terrain characteristics. Remote Sensing of Environment , 104 , 409-415. doi:10.1016/j.rse.2006.05.012. Hexagon Geospatial. (2016). ERDAS IMAGINE . Retrieved March 16, 2016, from http://www.hexagongeospatial.com/products/producer-suite/erdas-imagine

Hillen, M. , Jonkman, S. , Kanning, W. , Kok, M. , Geldenhuys, M. , \& Stive, M. (2010). Coastal defence cost estimates: case stydy of the Netherlands, New Orleans and Vietnam . Delft, Netherlands: TU Delft. Horritt, M. S. (2006). A methodology for the validation of uncertain flood inundation models. Journal of Hydrology , 326 (1-4), 153-165. doi:10.1016/j.jhydrol.2005.10.027.

Ibe, A. (1988). Coastline erosion in nigeria . Ibadan, Nigeria: University Press.

IPCC (1992). Intergovernmental panel on Climate Change Common Methodology. The Hague, Netherlands: IPCC- CZMS.

IPCC . (2007). Regional Impacts of Climate Change . IPCC. Retrieved November 17, 2015, from https://www.ipcc.ch/ipccreports/sres/regional/503.htm

IPCC . (2007a). Natural System responses to climate Change Drivers. Working group 11: Impacts, Adaptation and Vulnerability. Inter Governmental panel on Climate Change. Retrieved from http://www.ipcc.ch/publications_and_data/ar4/wg1/en/ch5s5-5-2-2.html

IPCC . (2007b). Deltas . Working group 11: Impacts, Adaptation and Vulnerability. Retrieved from Intergovernmental panel on Climate Change.

IPCC . (2013). Climate Change 2013: The Physical science Basis. Contribution of working group 1 to the Fifth Assessment Report of the Intergovernmental panel on Climate Change. Cambridge, UK: Cambrige University press. From http://www.ipcc.ch/pdf/assessment-

report/ar5/wg1/WG1AR5_Chapter13_FINAL.pdf

IPCC . (2013). Working group I contribution to the IPCC fifth assessment report (AR5), climate change 2013: the physical science basis. Stockholm: IPCC. Retrieved from

http://www.climatechange2013.org/images/uploads/WGIAR5_WGI-12Doc2b_FinalDraft_Chapter13.pdf Islam, R. Z. , Begum, S. F. , Yamaguchi, Y. , \& Ogawa, K. (2002). Distribution of suspended sediment in the coastal sea off the Ganges-Brahmaputra River mouth: observation from TM data. Marine Systems , 32 (4), 307-321. doi:10.1016/S0924-7963(02)00045-3.

Jarihani, A. , Callow, J. , Johansen, K. , \& Gouweleeuw, B. (2013). Evaluation of multiple satellite altimetry data for studying inland water bodies and river floods. Journal of Hydrology , 505 , 78-90.

doi:10.1016/j.jhydrol.2013.09.010.

Jarihani, A. , Callow, J. , McVicar, T. , Van Niel, T. , \& Larsen, J. (2015). Satellite-derived Digital Elevation Model (DEM) selection, preparation and correction for hydrodynamic modelling in large, low-gradient and data-sparse catchments. Journal of Hydrology , 524 , 489-506. doi:10.1016/j.jhydrol.2015.02.049. 
Jarihani, A. , McVicar, T. , Van Niel, T. , Emelyanova, I. , Callow, J. , \& Johansen, K. (2014). Blending Landsat and MODIS Data to Generate Multispectral Indices: A Comparison of "Index-then- Blend" and "Blend-then-Index" Approaches. Remote Sensing , 6 , 9213-9238 doi:10.3390/rs6109213.

Jena, P. , Panigrahi, B. , \& Chatterjee, C. (2016). Assessment of Cartosat-1 DEM for Modeling Floods in Data Scarce Regions. Water Resources Management , 30 , 1293-1309. doi:DOI 10.1007/s11269-0161226-9.

Jones, P. , Keating, K. , \& Pettit, A. (2015). Cost estimation for channel management summary of evidence. BrisTol: Environment Agency. Retrieved from http://evidence.environment-

agency.gov.uk/FCERM/Libraries/FCERM_Project_Documents/SC080039_cost_channel_mg mt.sflb.ashx Jonoski, A. \& Popescu, I. (2012). Distance Learning in Support of Water Resources Management: An Online Course on Decision Support Systems in River Basin Management. Water Resources Management , 26 (5), 1287-1305. doi:10.1007/s11269-011-9959-y.

Jung, C. H. , Hamski, J. , Durand, M. , Alsdorf, D. , Hossain, F. , Lee, H. , \& Hasan, K. (2010).

Characterization of complex fluvial systems using remote sensing of spatial and temporal water level variations in the Amazon, Congo, and Brahmaputra Rivers. Earth Surface Processes and Landforms , 35 (3), 294-304. doi:10.1002/esp.1914.

Karim, M. \& Mimura, N. (2008). Impacts of climate change and sea-level rise on cyclonic storm surge floods in Bangladesh. Global Environmental Change , 18 (3), 490-500.

doi:dx.doi.org/10.1016/j.gloenvcha.2008.05.002.

Karlsson, J. M. \& Arnberg, W. (2011). Quality analysis of SRTM and HYDRO1K: a case study of flood inundation in Mozambique. International Journal of Remote Sensing , 32 (1), 267-285.

doi:10.1080/01431160903464112.

Khan, S. I. , Hong, Y. , Vergara, H. J. , Gourley, J. J. , Brakenridge, G. R. , De Groeve, T. , \& Yong, B. (2012). Microwave Satllite Data for Hydrologic Modelling in Ungauged Basins. IEEE Geoscience and Remote Sensing Letters , 9 (4), doi:0.1109/LGRS.2011.2177807.

Kim, J. , Lu, Z. , Lee, H. , Shum, C. K. , Swarzenski, C. M. , Doyle, T. W. , \& Baek, S.-H. (2009). Integrated analysis of PALSAR/Radarsat-1 InSAR and ENVISAT altimeter data for mapping of absolute water level changes in Louisiana wetlands. Remote Sensing of Environment , 113 (11), 2356-2365.

Kiptala, J. , Mul, M. , Mohamed, Y. , \& Van der Zaag, P. (2014). Modelling stream flow and quantifying blue water using a modified STREAM model for a heterogeneous, highly utilized and data-scarce river basin in Africa. Hydrology and Earth Sytem Scieneces Journal (HESS) , 18, 2287-2303.

doi:10.5194/hess-18-2287-2014.

KPN.nl . (2017). Droogmakerij en Polderhistorie . Retrieved February 23, 2017, from http://home.kpn.nl/keesbolle/HoofdHist.html

Kumar, A. , Narayana, A. , \& Jayappa, K. (2010). Shoreline changes and morphology of spits along southern Karnataka, west coast of India: A remote sensing and statistics-based approach.

Geomorphology , 120 , 133-152. doi:10.1016/j.geomorph.2010.02.023.

Kumar, T. \& Kunte, P. (2012). Coastal Vulnerability Assessment for Chennai, East coast of India using Geospatial Techniques. Journal of Natural Hazards , 64 , 853-872.

Laukkonen, J. , Blancob, P.-K. , Lenhart, J. , Keinerd, M. , Cavrice, B. , \& Kinuthia-Njengaf, C. (2009).

Combining climate change adaptation and mitigation measures at the local level. Habitat International , 33

(3), 287-292. doi:10.1016/j.habitatint.2008.10.003.

Leauthaud, C. , Belaud, G. , Duvail, S. , \& Moussa, R. (2013). Characterizing floods in the poorly gauged wetlands of the Tana River Delta, Kenya, using a water balance model and satellite data. Hydrological Earth Systems Science , 17, 3059-3075. doi:10.5194/hess-17-3059-2013.

Leon, J. G. , Calmant, S. , Seyler, F., Bonnet, M.-P., Cauhope, M. , Frappart, F. , \& Fraizy, P. (2006). Rating curves and estimation of average water depth at the upper Negro. Journal of Hydrology, 328, 481-496. doi:10.1016/J.JHYDROL.2005.12.006.

Li, S. , Sun, D. , Goldberg, M. , \& Stefanidis, A. (2013). Derivation of 30-m-resolution water maps from TERRA/MODIS and SRTM. Remote Sensing of Environment , 134 , 417-430.

doi:10.1016/j.rse.2013.03.015.

Liew, S. C. , Gupta, A. , Wong, P. P. , \& Kwoha, L. K. (2010). Recovery from a large tsunami mapped over time: The Aceh coast. Sumatra. Geology , 114 (4), 520-529. doi:10.1016/j.geomorph.2009.08.010. Lillesand, T. , Kiefer, R. W. , \& Chapman, J. W. (2004). Remote sensing and image interpretation . (5th, Ed.) John Wiley and sons.

Long, S. , Fatoyinbo, T. , \& Policelli, F. (2014). Flood extent mapping for Namibia using change detection and thresholding with SAR. Environmental Research Letters , 9 (035002), doi:10.1088/1748-

9326/9/3/035002.

Martin, V. N. , Pires, R. , \& Cabral, P. (2012). Modelling of coastal vulnerability in the stretch between the beaches of Porto de Mos and Falesia, Algarve (Portugal). Journal of Coastal Conservation , 503-510, 
doi:DOI 10.1007/s11852-012-0191-6.

Mason, D. C. , Horritt, M. S. , Dall'Amico, J. T. , \& Scott, T. R. (2007). Improving River Flood Extent Delineation From Synthetic Aperture Radar Using Airborne Laser Altimetry. IEEE Transactions on Geoscience and Remote Sensing and (0196-2892), 3932 - 3943. doi:10.1109/TGRS.2007.901032 Mason, D. C. , Scott, T. R. , \& Dance, S. L. (2010). Remote sensing of intertidal morphological change in Morcambe Bay, U, K., between 1991 and 2007. Estuarine, Coastal and Shelf Science , 87, 487-496. doi:10.1016/j.ecss.2010.01.015.

Matgen, P. , Montanari, M. , Hostache, R. , Pfister, L. , Hoffmann, L. , Plaza, D. , \& Savenije, H. (2010). Towards the sequential assimilation of SAR-derived water stages into hydraulic models using the Particle Filter: proof of concept. Hydrology and Earth System Sciences , 14 , 1773-1785. doi:10.5194/hess-141773-2010.

Mclaughlin, S. \& Cooper, J. A. (2010). A multi-scale coastal vulnerability index: A tool for coastal managers? Environmental Hazards , 233-248, doi:10.3763/ehaz.2010.0052.

Mclaughlin, S. , Mckenna, J. , \& Cooper, J. (2002). Socio-economic Data in Coastal Vulnerability Indices: Constraints and Opportunities. Journal of coastal research , 487-489.

Mcmanus, J. (2002). Deltaic responses to Changes in River Regimes. marine Chemistry, 79, 155-170. Mcmillan, H. , Hreinsson, E. , Clark, M. , Singh, S. , Zammit, C. , \& Uddstrom, M. (2013). Operational hydrological data assimilation with the recursive ensemble Kalman filter. Hydrology and Earth System Sciences , 17 , 21-38. doi:10.5194/hess-17-21-2013.

Meijerink, A. M. , Bannert, D. , Batelaan, O. , Lubczynski, M. W. , \& Pointet, T. (2007). Remote sensing applictions to groundwater. Series on Groundwater: UNESCO.

Michelsen, N. , Dirks, H. , Al-Saud, M. , \& Schuth, C. (2016). YouTube as a crowd-generated water level archive. Science of the Total Environment , 568 (2016), 189-195. doi:doi:

10.1016/j.scitotenv.2016.05.211.

Middlesex community College (MXCC) . (2013). What is a database? Retrieved 0909 , 2016, from http://mxcc.edu/wp-ontent/uploads/2013/09/InternetVsDBs.pdf

Moya Quiroga, V. , Popescu, I. , \& Solomatine, D. (2013). Cloud and cluster computing in uncertainty analysis of integrated flood models. Journal of Hydroinformatics , $15,55-70$.

Muis, S. , Gunerap, B. , Jongman, B. , Aerts, C. J. H. , \& J., \& Ward, P., (2015). Flood risk and adaptation strategies under climate change and urban expansion: A probabilistic analysis using global data. Science of The Total Environment , 538, 445-457. doi:10.1016/j.scitotenv.2015.08.068.

Musa, Z. N. , Popescu, I. , \& Mynett, A. (2014b). Modelling the effects of sea level rise on flooding in the lower Niger River. 11 international conference on Hydro-informatics, HIC 2014. New York: HIC, 2014. Retrieved from https://www.conftool.pro/hic2014/index.php?page=browseSessions\&form_session=90 Musa, Z. , Popescu, I. , \& Mynett, A. (2014). Niger delta's vulnerability to river floods due to sea lavel rise. Natural Hazards and Earth System Science (NHESS) , 14 , 3317-3329. doi:10.5194/nhess- 14-33172014.

Musa, Z. , Popescu, I. , \& Mynett, A. (2015). A review of applications of satellite SAR, optical, altimetry and DEM data for surface water modelling, mapping and parameter estimation. Hydrology and Earth Sustems Sciences (HESS) , 19 , 3755-3769. doi:10.5194/hess- 19-3755-2015.

Musa, Z. , Popescu, I. , \& Mynett, A. (2016). Assessing the sustainability of local resilience practices against sea level riseimpacts on the lower Niger delta. Ocean and Coastal management , 130 (2016), 221-228. doi:doi: 10.1016/j.ocecoaman.2016.06.016.

Nairn, R. , Macintosh, K. , Hayes, M. , Nai, G. , Anthonio, S. , \& Valley, W. (1998). Coastal Erosion at Keta Lagoon, Ghana - Large Scale Solution to a Large Scale Problem. Journal of Coastal Engineering , 31923205. Retrieved from https://icce-ojs tamu.tdl.org/icce/index.php/icce/article/viewFile/5833/5501

NASA . (2012). Flooding in Nigeria . Retrieved 08 12, 2016, from

http://earthobservatory.nasa.gov/IOTD/view.php?id=79404

NBCC: National Black Chamber of Commerce . (2011). Sea Defense and Erosion Projects, Ghana .

Retrieved February 20, 2017, from https://www.nationalbcc.org/resources/contracting/1299-sea-defenseand-erosion-projects-ghana

NBS . (2011). Women in transforming Nigeria. Gender statistics newsletter: Quarterly publication of the Nigerian bureau for statistics , 2(4). Retrieved 12 12, 2016, from http://www. nigerianstat.gov.ng/report/39 NDDC . (2014). NDDC, making a difference: NDDC boss clears Ibeno mega bridge for commissioning promises more for niger delta . Retrieved December 15, 2015, from http://www.nddc.gov.ng/news_id5s.html NDRMP . (2004a). Niger Delta Regional Master Plan : Environment and Hydrology . NDRMP . (2004b). Niger Delta Regional Master Plan: Chapter 1. Niger Delta Region, Land and People. Abuja: NDDC. Retrieved 2015 ift.i 28-May from http://www.nddc.gov.ng/masterplan.html 
NDRMP . (2004c). Niger Delta Regional Master Plan. Chapter 2: Regional developement efforts . Abuja: NDDC. Retrieved May 28, 2015, from http://www.nddc.gov.ng/masterplan.html

NDRMP (2004d). Niger Delta Regional Master Plan: Environment and Hydrology Report . Port Harcourt, Nigeria: NNDC.

NEMA . (2010a). National Disaster Management Framework: Thematic Area 1 . Retrieved 01 14, 2013, from http://www.nema.gov.ng/documentation/ndmf/forward/acroabr/thematic-area-1.aspx

NEMA . (2010b). National disaster management frame work: thematic area 1 . Institutional capacity for disaster management. Retrieved 01 14, 2013, from

http://www.nema.gov.ng/documentation/ndmf/forward/acroabr/thematic-area-1.aspx

NEMA . (2010c). Retrieved from :www.nema.gov.ng/documentation/ndmf/forward/acroabr/thematic-area-

1.aspx

NEMA, Nigeria, N. (2013). NIGERIA: Post-Disaster Needs Assessment 2012 Floods . Abuja: World Bank. Retrieved August 09, 2016, from

https://www.gfdrr.org/sites/gfdrr/files/NIGERIA_PDNA_PRINT_05_29_2013_WEB.pdf

NEST . (2011). Reports of Research Projects on Impacts and Adaptation . Ibadan, Nigeria: Building

Nigeria's Response to Climate Change (BNRCC). Retrieved July 26, 2015

NEST , \& Woodley, E. (2011). Reports of Pilot Projects in Community-based Adaptation - Climate Change in Nigeria. Building Nigeria's Response to Climate Change (BNRCC) . Ibandan, Nigeria: BNRCC.

Retrieved from ISBN 978-0-9877568-9-3

Niang, I. , Ruppel, O. , Abdrabo, M. , Essel, A. , Lennard, C. , Padgham, J. , \& Urquhart, P. (2014). Part B: Regional Aspects. Contribution of Working Groupll to the Fifth Assessment Report of the

Intergovernmental Panel on Climate Change. In V. Barros, C. Field, D. Dokken, M. Mastrandrea, K. Mach , T. Bilir , ... L. White (Eds.), Climate Change 2014: Impacts, Adaptation, and Vulnerability . (pp. 1199-1265). Cambridge, United Kingdom and New York, NY, USA: IPCC. Retrieved 08 12, 2016, from http://www.ipcc.ch/pdf/assessment-report/ar5/wg2/WGIIAR5-Chap22_FINAL.pdf

Nicholls, R. , Wong, P. , Burkett, V. , \& Codi, J. (2007). Coastalsystems and low-lying areas. Climate Change 2007: Impacts, Adaptation and Vulnerability. Contribution of Working Group II to the Fourth Assessment Report of the Intergovernmental Panel on Climate Change . CambridgE, UK: Cambridge university press.

Nicolls, R. \& Mimura, N. (1998). Regional issues raised by sea-level rise and their policy implications. Journal of Climate Change , 5-18.

Nicolls, R. , Hoozemans, F. , \& Marchand, M. (1999). Increasing \#ood risk and wetland losses due to global sea-level rise: regional and global analyses. Global and Environmental Change , 9, S69-S87. doi:10.1016/S0959-3780(99)00019-9.

NOAA . (2012). Detailed methodology for mapping sea level rise inundation . Charleston, South Carolina 2: NOAA-Coastal services centre. Retrieved November 18,2015 , from

https://coast.noaa.gov/digitalcoast/_pdf/ElevationMappingConfidence.pdf

NOAA . (2016). Causes of coastal flooding . Retrieved December 25, 2016, from Storm surge and coastal inundation: http://www.stormsurge.noaa.gov/overview_causes.html

NOAA, S. I. (2015). Jason3 . Retrieved May 29, 2015, from http://www.nesdis.noaa.gov/jason-

3/?CFID=731ecb89-8379-48fc-ad50-959546e71739\&CFTOKEN $=0$

NPC . (2010). CENSUS ,Population distribution by state, sex, LGA and senatorial district. 2006 priority tables . Retrieved 2013 hh.i 14-01 from Available at: http://www.population.gov.ng

Nwilo, C. (1997). Managing the impact of Storm Surges in Victoria Island Nigeria. Destructive Waters: water caused natural disasters, their abatement and control (pp. 325-330). Califonia: IAHS.

Ogba, C. , \& Utang, P. (2007). vulnerability and adaptation of nigeria's niger delta coast settlements to climate change induced sea level rise. Strategic Integration of Surveying Services FIG Working week 2007 . Hong Kong SAR, China: FIG. Retrieved from

https://www.fig.net/resources/proceedings/fig_proceedings/fig2007/papers/ts_7b/ts07b_06_ogba_utang_1 342.pdf

Ogoro, M. (2014). Spatio - Temporal Changes in the Geomorphic Shoreline of Bonny Island. Journal of Research in Humanities and Social Science , 2 (11), 75-80.

Olomoda, I. (2012). 2012. Geostrategic Plan for Mitigation of Flood Disaster in Nigeria: Special

Publication of the Nigerian Association of Hydrological Sciences . Retrieved from

http://journal.unaab.edu.ng/index.php/NAHS.

Oosthoek, K. (2006). Dutch river defences in historical perspective . Retrieved February 23, 2017, from Environmental history resources: https://www.eh-resources.org/dutch-river-defences-in-historicalperspective/

Orupabo, S. (2008, January 01). Coastline Migration in Nigeria . Retrieved January 12, 2017, from Hydro International. Surveying in all waters: https://www.hydro-international.com/content/article/coastline- 
migration-in-nigeria

Owe, M. , Brubaker, K. , Ritchie, J. , \& Albert, R. (2001). Remote sensing and Hydrology, 2000. IAHS. Ozyurt, G. , \& Ergin, A. (2009). Application of sea level rise Vulnerability Assessment Model to Selected Coastal Areas of Turkey. Journal of Coastal Research (56), 248-251.

Ozyurt, G. \& Ergin, A. (2010). ) Improving Coastal Vulnerability Assessments to Sea-Level Rise: A New Indicator Based Methodology for Decision Makers. Journal of Coastal Research , 56 , 248-251.

Papa, F. , Bala, S. K. , Pandey, R. K. , Durand, F. , Gopalakrishna, V. V. , Rahman, A. , \& Rossow, W. B. (2012). Ganga-Brahmaputra river discharge from Jason-2 radar altimetry: An update to the long-term satellite-derived estimates of continental freshwater forcing flux into the Bay of Bengal. Journal of Geophysical Research, 117 (C11021), doi:10.1029/2012JC008158.

Pavelsky, T. , Morrow, R. , Peterson, C. , Andral, A. , Bronner, E. , \& Srinivasan, M. (2015). SWOT 101: A Quatum Improvement of Oceanography and Hydrology from the Next Generation Altimeter Mission . Retrieved May 29, 2015, from Surface Water and Ocean Topography:

https://swot.jpl.nasa.gov/files/swot/SWOT-101_Jan2015.pdf

Pendelton, E. , Barras, J. , Williams, S. , \& Twitchell, D. (2010). Coastal Vulnerability Assessment of the Northern Gulf of Mexico to Sea-Level Rise and Coastal Change . Retrieved from: USGS. http://pubs.usgs.gov/of/2010/1146 .

Penton, D. J. , \& Overton, I. C. (2007). Spatial modelling of floodplain inundation combining satellite imagery and elevation models. MODSIM 2007 International Congress on Modelling and Simulation . Modelling and Simulation Society of Australia and New Zealand.

Pereira-Cardenal, S. J. , Riegels, N. D. , Berry, P. A. , Smith, R. G. , Yakovlev, A. , Siegfried, T. U. , \& Bauer-Gottwein, P. (2011). Real-time remote sensing driven river basin modeling using radar altimetry. Hydrology and Earth sciences , 241-254 , doi:10.5194/hess-15-241-2011.

Pethick, J. \& Orford, J. (2013). Rapid rise in effective sea-level in southwest Bangladesh: Its causes and contemporary rates. Global and Planetary Change , 111 (2013), 237-245.

doi:dx.doi.org/10.1016/j.gloplacha.2013.09.019.

Pfeffer, W. T. , Harper, J. T. , \& O'neel, S. (2008, September 5). Kinematic Constraints on Glacier Contributions to 21st-Century Sea-Level Rise. Science , 32(5894), 1340-1343 . doi:doi:

10.1126/science.1159099

Popescu, I. , Cioaca, E. , Pan, Q. , Jonoskia, A. , \& Hanganu, J. (2015). Use of hydrodynamic models for the management of the Danube Delta wetlands: The case study of Sontea-Fortuna ecosystem.

Environmental Science \& Policy , 46 , 48-56. doi:dx.doi.org/10.1016/j.envsci.2014.01.012.

Price, R. (2009). An optimized routing model for flood forecasting. water Resources Research , 45 , W02426. doi:10.1029/2008WR007103.

Quinn, P. , Hewett, C.J.M. , Muste, M. , \& Popescu, I. (2010). Towards new types of water-centric collaboration. Proceedings of the Institution of Civil Engineers. Water Management, 163(1), 39-51. doi:DOI: 10.1680/wama.2010.163.1.39

Rahmstorf, S. (2007, January 19). A Semi-Empirical Approach to Projecting Future Sea-Level Rise. Science, 315 (5810), 368-370. doi:10.1126/science.1135456.

Ranasinghe, R. , Duong, T. , Uhlenbrook, S. , Roelvink, D. , \& Stive, M. (2012). Climate-change impact assessment for inlet-interrupted coastlines. Nature Climate Change , 3, 83-87.

doi:10.1038/nclimate1664.

Ricko, M. , Birkett, ,. C. , Carton, ,. J. , \& Cretauxc, J.-F. (2012). Intercomparison and validation of continental water. Journal of Applied Remote Sensing , 6. Retrieved from spiedigitallibrary.org/ on 03/12/2013 Terms of Use: http://spiedl.org/terms

Rijsberman, F. (1996). Rapportteurs statement: coastal resources. In S. S. Media, Adapating to climate change: an international perspective (pp. 279-282). New York : Springer. doi:10.1007/978-1-4613-8473-1 Rosmorduc, V. (2012). EO Information Services in support of West Africa Coastal vulnerability. Service 2 : Sea Level Height \& currents. Washington DC: World bank. Retrieved from http://siteresources.worldbank.org/EXTEOFD/Resources/8426770-1335964503411/SUR-CWest_Africa_Coastal_vulnerability_Service2.pdf

Santos da Silva, J. , Roux, E. , Filho, O. , Bonne, M. P. , Seyler, F. , \& Calmant, S. (2007). 3D selection of Envisat data for improved water stage times series on the Rio Negro and adjacent Wetlands (Amazon Basin). 2nd Hydrospace Workshop. Geneva: ESA.

Santos da Silver, J. , Calmant, S. , Seyler, F. , Lee, H. , \& Shum, C. (2012). Mapping of the extreme stage variations using ENVISAT altimetry in the Amazon basin rivers. International Water Technology Journal, IWTJ , 2 (1), 14-25 . Retrieved from http://iwtj.info/wp-content/uploads/2012/11/V2-N1-p2.pdf.

Sanyal, J. \& Carbonneau, P. (2012). Low-cost, open access flood inundation modelling with sparse data: A case study of the Lower Damodar River Basin . India : EGU. 
Sarhadi, A. , Soltani, S. , \& Modarres, R. (2012). Probabilistic flood inundation mapping of ungauged rivers: Linking GIS techniques and frequency analysis. Journal of Hydrology , 458-459, 6886.

doi:10.1016/j.jhydrol.2012.06.039.

Schielen, R. M. (2010). Flood management. In R. C. Ferrier , \& A. Jenkins (Eds.), A handbook of catchment management (pp. 51 - 76). Wiley-Blackwell.

Schumann, G. J.-P. , Bates, P. , Neal, J. , \& Andreadis, K. (2015). Measuring and Mapping Flood processes. In P. Paron \& G. Di Baldassare (Eds.), Hydro-Meteorological Hazards, Risks, and Disasters (pp. 35-64). Amsterdam, Netherlands: Elsevier.

Schumann, G. J.-P. , Neal, J. , Voisin, N. , Andreadis, K. , Pappenberger, F. , Phanthuwongpakdee, N. , \& Bates, P. (2013). A first large-scale flood inundation forecasting model. Water Resources Research , 49 , 6248-6257. doi:10.1002/wrcr.20521, 2013.

Schumann, G. , Matgen, P. , Cutler, M. , Black, A. , Hoffmann, L. , \& Pfister, L. (2008). Comparison of remotely sensed water stages from LiDAR, topographic contours and SRTM. Photogrammetry and Remote Sensing , 63 , 283-296. doi:10.1016/j.isprsjprs.2007.09.004.

Schumann, G. , Matgen, P. , Hoffmann, L. , Hostache, R. , Pappenberger, F. , \& Pfister, L. (2007). Deriving distributed roughness values from satellite radar data for flood inundation modelling. Journal of Hydrology , 344 (1-2), 96-111. doi:10.1016/j.jhydrol.2007.06.024.

Schumann, G. , Matgen, P. , Pappenberger, F. , Black, A. , Cutler, M. , Hoffmann, L. , \& Pfister, L. (2006). The REFIX model: remote sensing based flood modelling. ISPRS Commission VII Mid-term Symposium "Remote Sensing: From Pixels to Processes. Enschede, the Netherlands: ISPRS commission.

Seyler, F. , Calmant, S. , Santos da Silva, J. , Leon, G. J. , Frappart, F. , Bonnet, M.-P. , . . Seyler, P. (2009). New perspectives in monitoring water resources in large tropical transboundary basins based on the combined used of remote sensing and radar altimetry. Improving Integrated Surface and Groundwater Resources Management in a Vulnerable and Changing World , pp. 282-288. doi:10.13140/2.1.5101.0569 Shell, E. (2004). Environmental impact assessment for the utorogu NAG . Shell Nigeria. Retrieved 2015 hhj 26-May from http://s06.static-shell.com/content/dam/shell/static/nga/downloads/environmentsociety/eia-reports/utorogu-nag-wells-eiareport.pdf Shell, E. (2006). Environmental Impact Assessment of Rumuekpe (Om/ 22) and Etelebou (Oml 28) 3d Seismic Survey. The Shell Petroleum Development Company of Nigeria Limited. From http://s04.staticshell.com/content/dam/shell-new/local/country/nga/downloads/pdf/rumuekpe-eia-report.pdf

Shell, N. (2015). Environment and society:Oil spill data . Retrieved May 22, 2015, from http://www.shell.com.ng/environment-society/environment-tpkg/oil-spills.html Siddique-E-Akbor, A. H. , Hossain, F. , Lee, H. , \& Shum, C. K. (2011). Inter-comparison study of water level estimates derived from. Remote Sensing of Environment, 115 (6), 522-1531. doi:10.1016/j.rse.2011.02.011.

Skakun, S. (2010). A neural network approach to flood mapping using satellite imagery. Computing and Informatics , 29 , 1013-1024.

Smith, L. C. (1997). Satellite Remote Sensing of River Innundation Area, Stage and Discharge: A review. Hydrological Processes , 11, 1427-1439.

Smith, L. , Liang, Q. , James, P. , \& Lin, W. (2015). Assessing the utility of social media as a data source for flood risk management using a real-time modelling framework: Assessing the utility of social media for flood risk management. Journal of Flood Risk Management , 1-11, doi:10.1111/jfr3.12154.

Sorensen, R. , Weisman, R. , \& Lennon, G. (1984). Control of Erosion, Inundation and Salinity Intrusion Caused by Sea Level Rise. In BARTH, M., \& TITUS, J. (Eds.), Green House Effect and Sea Level Rise: A Challenge for This Generation. 1st ed (pp. 179-214). Van Nostrand Reinhold Company.

Stephens, E. , Bates, P. , Freer, J. , \& Mason, D. (2012). The impact of uncertainty in satellite data on the assessment of flood inundation models. Journal of Hydrology , 414-415, 162-173.

doi:10.1016/j.jhydrol.2011.10.040.

Structurae . (1997). Maeslant Barrier . Retrieved from https://structurae.net/about/terms/

Sugiura, A. , Fujioka, S. , Nabesaka, S. , Sayama, T. , Iwami, Y., Fukami, K. , . . Takeuchi, K. (2013).

Challenges on modelling a large river basin with scarce data: A case study of the Indus upper catchment.

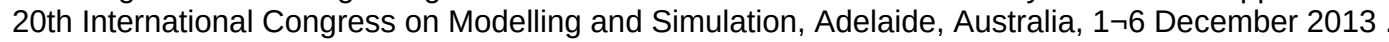
Adelaide, Australia. Retrieved from www.mssanz.org.au/modsim2013

Sun, W. , Ishidaira, H. , \& BasTola, S. (2009). Estimating discharge by calibrating hydrological model against water surface width measured from satellites in large ungauged basins. Annual Journal of Hydraulic Engineering , 53, 49-54.

Sun, W. , Ishidaira, H. , \& BasTola, S. (2010). Towards improving river discharge estimation in ungauged basins: calibration of rainfall-runoff models based on satellite observations of river flow width at basin outlet. Hydrology and Earth Sysytem Sciences , 14 , 2011-2022. doi:10.5194/hess-14-2011-2010. 
Syvitski, J. P. (2008). Deltas at risk. Sustainable. Science , 3 , 23-32. doi:10.1007/s11625-008-0043-3. Syvitski, J. P. , Overeem, I. , Brakenridge, R. G. , \& Hannon, M. (2012). Floods, floodplains, delta plains - A satellite imaging approach. Sedimentary Geology , 267-268, 1-14.

doi:10.1016/j.sedgeo.2012.05.014.

Tarpanelli, A. , Barbetta, S. , Brocca, L. , \& Moramarco, T. (2013). River Discharge Estimation by Using Altimetry Data and Simplified Flood Routing Modeling. Remote Sensing , 5, 41454162.

doi:10.3390/rs5094145.

Thieler, E. , \& Hammer-Kloss, E. (1999). National Assessment of Coastal Vulnerability to Future SeaLevel Rise: Preliminary Results for the U.S. Atlantic Coast . US Geological Survey. Tides4Fishing . (2016). Tides and solunar charts . Retrieved march 01, 2016, from http://www.tides4fishing.com/af/nigeria/ford-point

Tilmans, W. , Jakobsen, P. , \& LeClerc, J.-P. (1991). Coastal erosion in the Bight of Benin: a critical review. Delft: Delft Hydraulics.

Tol, S. (2007). the double trade off between adaptation and mitigation for sea level rise: an application of fund. mitigation and adaptation strategies. Global Change , 12, 741-753.

Tulloch, J. (2016). Dutch flood protection: Taming the water wolf . Retrieved February 24, 2017, from Allianz: https://www.allianz.com/en/about_us/open-knowledge/topics/environment/articles/100311-dutchflood-protection-taming-the-water-wolf.html/

Twmasi, Y. \& Merem, E. (2006). GIS and Remote Sensing Applications in the Assessment of Change within a Coastal Environment in the Niger Delta Region of Nigeria. International Journal of Environmental Research and Public Health , 3 (3), 98-106.

UK Hydrographic office: Almiralty Easy Tide. (n.d.). Your EasyTide Prediction . Retrieved 01 29, 2016, from http://www.ukho.gov.uk/easytide/easytide/ShowPrediction.aspx?PortID=3663\&PredictionLength=7 UNFPA . (2008). Population and Climate Change Framework of UNFPA's Agenda . Retrieved 0305 , 2013, from Climate change: http://www.unfpa.org/pds/climate_change_unfpa.pdf

US Army Corps of Engineers . (2009). Louisiana coastal protection and restoration (LACPR) final technical report . Mississippi Valley U.S.A: U. S. Army Corps of Engineers. Retrieved from http://www.mvn.usace.army.mil/Portals/56/docs/environmental/LaCPR/LACPRFinalTechnicalReportJune2 009.pdf

Utretcht University: Faculty of Geosciences . (2007). Rhine - Muese delta studies: Flooding . Retrieved March 06, 2017, from http://www.geo.uu.nl/fg/palaeogeography/results/flooding

Uy, N. , Takeuchia, Y. , \& Shawa, R. (2011). Local adaptation for livelihood resilience in Albay,

Philippines. Environmental Hazards , 10 (2), doi:10.1080/17477891.2011.579338.

Uyigue, E. (2007). Climate change in the Niger delta . Retrieved from CIEL.ORG:

www.ciel.org/Publications/Climate/CaseStudy_Nigeria_Dec07.pdf

Uyigue, E. (2009). The Changing Climate and the Niger Delta. CREDC. Retrieved 2015 hh.i 20-11 from

http://www.climatefrontlines.org/sites/default/files/The\%20Changing\%20Climate\%20

and\%20the\%20Niger\%20Delta.pdf

Uyigue, E. \& Agwo, M. (2007). Coping with climate change and environmental degradation in the Niger delta of southern Nigeria . Benin city, Nigeria: CREDC.

Uzukwu, P. , Leton, P. , \& Jamabo, N. (2014). Survey of the physical charecteristics of the upper reach of the New-Calabar river, Niger delta Nigeria. Trends in Aplied Sciences Research , 9 (9), 494502.

doi:10.3923/tasr.2014.494.502.

Van Bentum, K. (2012). The Lagos coast - Investigation of the long-term morphological impact of the Eko Atlantic City project . T.U Delft. Delft: Delft University of Technology. Retrieved from

http://resolver.tuDelft.nl/uuid:794318f9-9279-4a3c-9030-2f9fab7c6562

van der Burgh, L. (2008). Risk and coastal zone policy: example from the Netherlands . Retrieved March 07, 2017, from

http://www.coastalwiki.org/wiki/Risk_and_coastal_zone_policy:_example_from_the_Netherlands Van Heerden, I. (2007). The Failure of the New Orleans Levee System Following Hurricane Katrina and the Pathway Forward. Public Administration Review , 67(2007), 24-35. Retrieved from

www.jstor.org/stable/4624679

Van, P. , Popescu, I. , Van Griensven, A., Solomatine, D. , Trung, N. , \& Green, A. (2012). A study of the climate change impacts on fluvial flood propagation in the Vietnamese Mekong Delta. Hydrology and Earth Systems Science , 16 , 4637-4649. doi:doi:10.5194/hess-16-4637-2012.

Vermeulen, C. J. , Barneveld, H. J. , Huizinga, H. J. , \& Havinga, F. J. (2005). Data-assimilation in flood forecasting using time series and satellite data. International conference on innovation advances and implementation of flood forcasting technology. Tromso: ACTIF/Floodman/FloodRelief.

Villladsen, H. , Andersen, O. , \& Stenseng, L. (2014). Annual cycle in lakes and rivers from Cryosat-2 altimetry - the Brahmaputra river. International Geoscience and Remote Sensing Symposium (IGARSS) 
(pp. 894-897). Quebec, canada: IEEE. doi:978-1-4799-5775-0/14

Wesselink, A. , Abu Syed, M. , Chan, F. , Duc Tran, D. , Huq, H. , Huthoff, F. , \& Zegwaard, A. (2015). International Journal of Water Governance , 3 (4), 25-46. doi:10.7564/15-IJWG90.

Westahoff, R. , Huizinga, J. , Kleuskens, M. , Burren, R. , \& Casey, S. (2010). ESA Living Planet Symposium. 686. Bergen, Norway: ESA Communications.

Williams, S. \& Ismail, N. (2015). Climate Change, Coastal Vulnerability and the Need for Adaptation Alternatives: Planning and Design Examples from Egypt and the USA. Marine Science and ENgineering , 3 (2015), 591-606. doi:10.3390/jmse3030591.

Woldemicheal, A. , Degu, A. , Siddique-E-Akbor, A. , \& Hossain, F. (2010). Role of Land-Water

Classification and Manning's Roughness Parameter in Space-Borne Estimation of Discharge for Braided Rivers: A Case Study of the Brahmaputra River in Bangladesh. leee journal of selected topics in applied earth observations and remote sensing ,. doi:10.1109/jstars.2010.2050579.

Woody, T. (2015). Will the 'Great Wall' of New Orleans Save It From the Next Killer Hurricane? Retrieved January 22, 2017, from http://www.takepart.com/feature/2015/08/17/katrina-new- orleans-walled-city World Bank (2016). inception report: Cost of Coastal Environmental Degradation, Multi Hazard Risk Assessment and Cost Benefit Analysis . Belgium: World bank.

World Population Review. (2017, February 08). Lagos Population 2017 . Retrieved 02 19, 2017, from World Population Review: http://worldpopulationreview.com/world-cities/lagos-population/

Yan, K. , Di Baldassarre, G. , Solomatine, D. , \& Schumann, G. (2015). A review of low-cost space- borne data for flood modelling:topography, flood extent and water level. Hydrological processes , 29 (14), 3368-3387. doi:10.1002/hyp.10449.

Yan, K. , Di Baldassarre, G. , Solomatine, D. , \& Schumann, G. (2015). A review of low-cost space- borne data for flood modelling:topography, flood extent and water level. Hydrological processes ,.

doi:10.1002/hyp.10449.

Yang, C. \& Ouchic, K. (2012). Analysis of bar morphology using multi-temporal and multi-sensor satellite images: Example from the Han Estuary, Korea. Marine Geology, 311-314, 17-31.

doi:10.1016/j.margeo.2012.04.004.

Yin, J. , Yin, Z. , Wang, J. , \& Xu, S. (2012). National Assessment of Coastal Vulnerability to Sea- Level Rise for the Chinese coast. Journal of coastal Conservation , 16, 123-133.

Zhang, J. , Xu, K. , Yang, Y. , Qi, L. , Hayashi, S. , \& Watanabe, M. (2006). Measuring water storage fluctuations in Lake Dongting, China, by Topex/Poseidon satellite altimetry. Environmental Monitoring and Assessment , 115 , 23-37. doi:10.1007/s10661-006-5233-9. 